$$
\text { UNIVERSIDADE DE SÃO PAULO }
$$

FACULDADE DE FILOSOFIA, LETRAS E CIÊNCIAS HUMANAS DEPARTAMENTO DE LETRAS MODERNAS

PROGRAMA DE PÓS-GRADUAÇÃO EM LÍNGUA E LITERATURA FRANCESA

\title{
A MEMÓRIA DO SONHO \\ Um estudo sobre a tradição oral e seus porta-vozes, os contadores de histórias
}

Heloisa Braz de Oliveira Prieto

\begin{abstract}
Tese apresentada ao Programa de PósGraduação em Língua e Literatura Francesa, do Departamento de Letras Modernas da Faculdade de Filosofia, Letras e Ciências Humanas da Universidade de São Paulo, para obtenção do título de Doutora em Língua e Literatura Francesa.
\end{abstract}

Orientador: Prof. Dr. Philippe Willemart 
UNIVERSIDADE DE SÃO PAULO

FACULDADE DE FILOSOFIA, LETRAS E CIÊNCIAS HUMANAS

DEPARTAMENTO DE LETRAS MODERNAS

PROGRAMA DE PÓS-GRADUAÇÃO EM LÍNGUA E LITERATURA FRANCESA

\section{A MEMÓRIA DO SONHO \\ Um estudo sobre a tradição oral e seus porta-vozes, os contadores de histórias}

Heloisa Braz de Oliveira Prieto

São Paulo

2006 
Dedicatória

Para meus filhos,

Lucas e Priscila Prieto Nemeth. 


\section{Agradecimentos}

Agradeço a Cecilia Almeida Salles, pelo estímulo constante, por sugestões bibliográficas e leituras críticas ao longo do processo de criação desta tese; a Tânia Centurion, pela amizade sincera e incondicional; a meu pai, Luiz Felippe Prieto, guardião zeloso dos arquivos virtuais e interlocutor constante; a Paulo Vicente Bloise, cujas palavras sempre conferem nova luminosidade ao percurso dos caminhos literários, por me instigar a escrever textos teóricos, apoiando o apuro de meu pensamento ao aproximar-me do universo da psicologia analítica; e a Philippe Willemart, professor admirado durante meu curso de graduação em Língua e Literatura Francesa, orientador de ampla visão acadêmica, amigo paciente nas horas mais difíceis. 


\section{Resumo}

Memória da Cultura, textos constantes e textos excluídos pelo esquecimento. A memória do sonho como a primeira obra de ficção jamais criada pelo homem. O sonho enquanto embrião narrativo de fábulas. Cânones, mecanismos culturais de controle. A performance da palavra. A movência das narrativas orais. O projeto poético e a rede intersemiótica de criação. Inconsciente coletivo, matizes arquetípicos e o mar como metáfora da metáfora do manancial das fábulas imemoriais. 


\section{Abstract}

The memory of culture, constant texts versus excluded texts, fables doomed to be forgotten. Remembering dreams as the first work of fiction ever created by mankind. Dreaming as telling tales. Standards as cultural controlling devices. Words as performances. Travelling through oral folktales. Poets and their artistic approach to life, plus the intersemiotic net for art creation. Unconscious collective, archetypical blending of nuances and the sea as the universal metaphor of the everlasting source of long forgotten fables. 


\section{Palavras-Chave/Key Words}

Contador de história, tradição oral, memória, esquecimento, sonho.

Storyteller, oral tradition, memory, forgetfulness, dream. 


\section{Sumário}

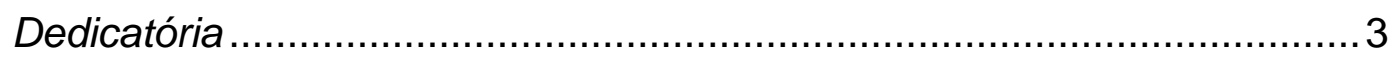

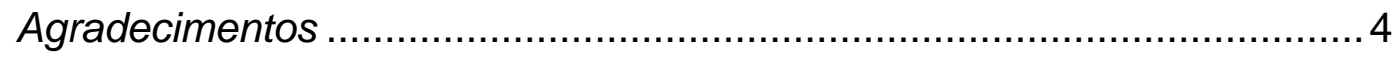

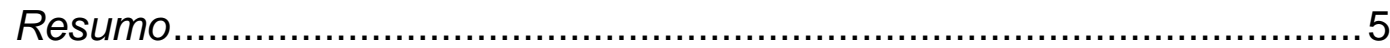

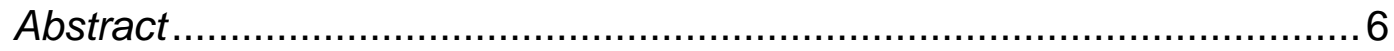

Palavras-chave/key words ........................................................ 7

Apresentação

A Biblioteca Secreta de Cada Um ............................................... 10

Capítulo 1

Memória, Filha de Urano e Gaia ......................................... 17

Capítulo 2

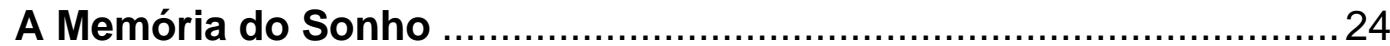

Capítulo 3

A Memória da Cultura ................................................................ 31

Capítulo 4

A Memória do Gesto Criador. 38 
Capítulo 5

A Memória da Voz

Capítulo 6

Narrativas Imemoriais

Capítulo 7

Os Caminhos da Memória

69

Posfácio

89

Bibliografia

92 
Apresentação

A Biblioteca Secreta de Cada Um 
Quando eu era garota e caía, minha avó Leonor Prieto me punha no colo e contava uma história. Quando eu queria entender o mundo dos adultos e não conseguia, ela me dava um livro dizendo: "Para saber ler a vida, a gente precisa saber ler os livros". Portanto, cresci acreditando que o mundo era repleto de histórias e que, se eu prestasse atenção nelas, seria capaz de viver melhor, com mais alegria e tranqüilidade.

Infelizmente quase não pude conhecer meu avô, Thomaz Prieto, que morreu quando eu tinha apenas quatro anos. Porém, há pouco tempo, recebi de presente os livros que pertenciam a sua biblioteca. Emocionada, fui

folheando os volumes antigos e descobrindo que tínhamos uma coisa em comum: o amor pelas histórias de aventura, suspense e mistério. Era como se aqueles livros formassem uma ponte que me levava ao mundo onde ele vivera e eu pudesse, de algum modo, estar ao seu lado outra vez.

Se você quiser conhecer alguém profundamente, preste atenção nas histórias que essa pessoa conta, lê ou assiste na televisão ou no cinema. Nossas histórias preferidas sempre falam de nossos maiores segredos, das emoções mais verdadeiras de nossas vidas, dos nossos sonhos e esperanças.

Na antiga Grécia se contava que o trabalho dos escritores e contadores de histórias era inspirado pelas musas. A inspiração era um presente dessas belíssimas criaturas mágicas que flutuavam ao redor dos artistas. Calíope era o nome da musa da poesia e Clio era a musa da história. A mãe dessas musas era Mnemósine, a deusa da memória. Talvez seja por isso que as melhores histórias que ouvimos ficam guardadas na nossa memória e, cada vez que as narramos, parecem trazer uma novidade, um sabor de juventude, a lembrança poderosa de uma forte emoção. Heloisa Prieto, Lá vem história. 


\section{A Biblioteca Secreta de Cada Um}

A escritura desta tese coincidiu com minha mudança de residência. O que esses dois fatos teriam em comum? Um questionamento sobre os livros fundamentais em minha vida.

Transportar uma biblioteca não é tarefa fácil e decidir que livros deveriam ser doados, preservados, qual o espaço para os novos livros foram perguntas que me assombraram durante meses.

Finalmente instalada em nova residência, outra vez me encontro diante das estantes ao escrever a bibliografia da tese. Como na teoria do semioticista luri Lotman, a respeito da memória cultural, deparei com aqueles que seriam os textos constantes em minha vida: autores como Proust, Borges, Edgard Allan Poe, Fernando Pessoa, Carl Gustav Jung, Freud. Bem como com os textos móveis, livros que, no passado, pareciam exercer um fascínio profundo, mas que raramente foram retomados, embora continuassem ocupando em minhas estantes um lugar apenas reservado aos entes mais queridos. A rica obra de Jean Piaget, por exemplo, certamente influenciou a maneira como escrevo para crianças, lançando mais dúvidas do que oferecendo respostas. A poesia de T. S. Eliot, lida reiteradamente nos tempos de juventude, pertencia à minha cabeceira, um lugar hoje ocupado pela obra da poetisa Sylvia Plath, autora que me foi apresentada pelo escritor e psiquiatra Paulo Vicente Bloise, interlocutor constante em minhas recentes buscas literárias.

Todos esses diálogos a respeito de livros, na maioria das vezes, acabaram gerando novos livros. De modo que as conversas sobre Jung e Plath produziram a antologia Vida crônica, publicada pela Companhia das Letras, em coautoria com Bloise; Proust permaneceu como um elo profundo entre mim e meu atual orientador, e ex-professor no curso de graduação, Philippe Willemart. Nossas 
incursões no universo proustiano, por sua vez, conduziram à descoberta da importância de obras como As mil e uma noites. Sherazade, a maravilhosa contadora de histórias, apresentou-me o caminho do sufismo e a relevância das tradições árabes em autores do século XX, como Doris Lessing e Robert Graves. Autores que eu lia há anos sem perceber o texto sufi subliminar que, por sua vez, os ligava ao imaginário borgiano, cuja obra se espalhava por minhas estantes desde os 25 anos.

O processo de escritura desta tese foi excepcionalmente longo. Em vários momentos, senti vontade de desistir do desafio, encontrando muita dificuldade em conciliar a carreira de escritora com o tempo exigido pelo rigor da pesquisa acadêmica. Nesses momentos, Willemart insistia, afirmando que não eram caminhos excludentes e que eu poderia, de qualquer modo, contribuir com um depoimento sobre meu próprio processo de criação.

Acontece que, como a maioria dos escritores, eu não tinha um pensamento formal sobre a maneira como criava minha literatura. Foi por meio de conversas com Cecilia de Almeida Salles e pelo contato com a reflexão expressa na obra dela que pude ter consciência dos caminhos que percorria.

Cecilia Almeida Salles, em seu livro Gesto inacabado (p. 36), afirma:

Muitos artistas descrevem a criação como um percurso do caos ao cosmos. Um acúmulo de idéias, planos e possibilidades que vão sendo selecionados e combinados. As combinações, por sua vez, são testadas e, assim, opções são feitas, e um objeto com organização própria vai surgindo. O objeto artístico é construído desse anseio por uma forma de organização.

A consciência do diálogo que eu estabelecia com a literatura oral, com a biblioteca herdada de meus avós, enriqueceu meu trabalho criativo. Perceber os próprios passos encheu-me de coragem para tentar novos passos e enveredar-me pela literatura "adulta", por assim dizer. 
Mas será que existe mesmo uma rígida fronteira divisória entre leitores mirins e adultos? Essa questão remeteu-me à história da literatura, tema que eu estudara exaustivamente ao longo da graduação. Porém, qual não foi minha surpresa ao descobrir que, enquanto habitante desse universo tão próprio que é o mundo dos escritores profissionais, eu não encontrava escolas ou movimentos formalizados, embora a escolha dos companheiros literários para as antologias e projetos editoriais que organizei ao longo dos anos apontasse para afinidades mais profundas do que rótulos como "literatura regional", "literatura urbana", "literatura de vanguarda" e, finalmente, "alta literatura" e "literatura de entretenimento". A organização simplista dos manuais de história da literatura, descrevendo escolas rígidas, posturas definitivas, obviamente se distanciava da condição de metamorfose permanente que caracterizava as opções e contradições próprias ao ato criador.

Enquanto eu pensava sobre essas discrepâncias entre teoria e prática, as crianças, minhas leitoras, perguntavam insistentemente:

— De onde você tira suas idéias?

- Como você se inspira para criar?

Impossível mentir para crianças! Todavia, ao tentar responder sinceramente a essas perguntas, muitas vezes eu percebia que surpreendia as professoras que as conduziam até mim, talvez, ao contrariar as teorias já elaboradas por elas a respeito do processo criativo dos escritores profissionais.

Haveria uma musa?

E lá fui eu, dicionários de mitologia grega em mãos, descobrir mais a respeito do mito de Mnemósine, a musa da memória, mãe de toda criação. Ao contrário do mito do escritor romântico e a musa impossível de ser atingida, o mito da deusa grega continha grande sabedoria no sentido de alicerçar a criação na lembrança. Nada surge do nada.

Em sua obra mais recente, Willemart (2005, p. 12) ataca a crítica convencional propondo uma nova história da literatura, "que não partirá mais das origens para o presente, mas lerá o passado à luz do presente". 
Tal concepção vai ao encontro das palavras de Paulo Rónai e Aurélio Buarque de Holanda Ferreira (1978, pp. 13-4), apontando para a atemporalidade orgânica da obra literária, no maravilhoso prefácio à coletânea intitulada Mar de histórias:

O nome sânscrito Kathâsaritsâgara graças a possibilidades de síntese que faltam ao português, significa, mesmo, "Mar formado pelos rios de histórias". Com efeito, quanto mais o pesquisador se detém a observar a infinita multidão de contos, seu incessante movimento, suas metamorfoses contínuas, suas riquezas de cores, matizes e formas, tanto mais justo se the revela o símile do antigo compilador hindu Somadeva. São eles, realmente, como as ondas de um mar, alimentado por inúmeros rios originários dos países mais diversos, e muitos oriundos de escondidas fontes. De um mar que liga os povos das margens, que thes confunde as vozes e as tradições, que lhe faz trocar os produtos.

Conforme ressalta Lotman, em teoria que abordaremos com maior amplitude ao longo desta tese, o contraponto da memória é o esquecimento.

— Onde você guarda as obras de Nelson Rodrigues? — indagou Paulo Bloise, enquanto observava os livros de minha biblioteca.

Rodrigues fora objeto de estudo obrigatório durante minha graduação, mas eu simplesmente me desfizera de seus livros. Por que seus títulos não podiam pertencer às minhas estantes?

A resposta a essa pergunta levou-me a pensar em outros ódios de estimação familiares, como ao jornalista Paulo Francis, autor também detestado por meu pai, Luiz Prieto, cuja biblioteca não dispensava as obras dos autores como John Steinbeck, Ernest Hemingway e Rachel de Queiroz. Escritores que ele considerava como fortes e corajosos, ao contrário de Rodrigues, desprezado pela fraqueza e indolência. Ou seja, mesmo no universo íntimo e pessoal de cada leitor, a escolha dos textos oficiais se contrapõe à exclusão de obras consideradas como 
desqualificadas. Contudo, a exclusão muitas vezes gera um poder maior do que o reconhecimento ostensivo. Fato que todo jovem reconhece como verdadeiro. Então, durante minha juventude, se Rodrigues e todo o nilismo de sua literatura eram proibidos, nada como mergulhar nas Relações perigosas, de Choderlos de Laclos, um livro que viria a tornar-se uma presença constante em minha biblioteca.

Um gesto aparentemente tão corriqueiro, como anotar os títulos de uma estante para montar uma bibliografia, à luz da teoria de Lotman, ganhou novos significados, produzindo descobertas que, por sua vez, enriqueceram não só esta tese como minha produção literária ao longo de sua escritura.

Ao concluir este trabalho, percebo que o ofício do escritor em muito se assemelha ao de um navegante, ao sabor das intempéries marinhas, ou ao de um agricultor, que espalha várias sementes e se surpreende pelo surgimento dos brotos nos terrenos mais improváveis.

Mesclando o estudo teórico a depoimentos e fábulas, percebo ter percorrido caminhos acadêmicos aparentemente inusitados, mas que, ao menos para mim, formam um tecido orgânico, cuja intenção era suscitar a curiosidade e a fome de reflexão. Afinal, respostas nunca devem ser definitivas, pois, como diria Lao-Tsé (apud Bloise, 2000, p. 23) na antiga China...

As palavras não são bonitas;

As palavras bonitas não são verdadeiras.

O bom homem não discute;

Aquele que discute não é um bom homem.

O sábio não é erudito;

O erudito não é sábio. 
Capítulo 1

Memória, Filha de Urano e Gaia 
Mnemósine é a personificação da memória. Filha de Urano e Gaia, pertence ao grupo das Titanidias.

Zeus uniu-se a ela em Pierie, durante nove dias consecutivos, e, ao término de um ano, ela lhe deu nove filhas, as musas.

Pierre Grimal, Dicionário de mitologia greco-romana. 


\section{Memória, Filha de Urano e Gaia}

Em seu belo estudo sobre o trabalho de Proust, autor cuja obra gira em torno de um processo de redescoberta de si mesmo, por meio de uma investigação sutil, poética e minuciosa de seu passado sentimental, Philippe Willemart (2000, p. 192) descreve a relação do narrador com a memória como uma rede:

A idéia da rede, criando transversais, permite a comunicação entre dois caminhos de Swann e de Guermantes, desdobra-se no texto com a de revolução - que realizava em torno não só de si mesmo como dos outros. O tempo que corre não será mais aquele do calendário eliminado na evocação das lembranças, não será também o tempo lógico que articula o analisando com seu passado. Será aquele, infinitamente mais longo, das voltas que cada um faz ao redor de si mesmo ou dos outros criando com este movimento um espaço diferente composto de planos superpostos. O tempo não seguirá mais a ordem linear do calendário, nem a ordem hipertextual da análise na qual o analista, sublinhando uma palavra, obriga o analisando a bifurcar em seu discurso, mas o tempo será galáctico.

Prosseguindo em seu raciocínio, Willemart (2000, pp. 192-3) propõe a metáfora de uma mesma galáxia onde os planetas e as estrelas, em constante movimento, constituiriam novos mundos. Nesses espaços de interação criativa,

o avanço do tempo mede a distância percorrida e a complexidade crescente da galáxia pessoal. A multiplicidade dos encontros, pessoas, livros ou obras é benéfica e revela-se um verdadeiro processo de aculturação 
sabendo-se, porém, que é preciso fazer tantas revoluções quantas foram necessárias para criar um largo espaço memorável.

Acrescenta ainda, à imagem de um espaço orgânico de fecunda sensibilidade, em constante modificação, a definição de uma

memória espacial que será formada a partir de sites, locais de que se serviam os sábios da Idade Média seguidores dos antigos, para reter as informações que chegavam. O conhecimento de si mesmo e dos outros será decorrente dos diferentes monumentos ou lugares onde vivemos, que conhecemos e em que encontramos os outros. (Willemart, 2000, p. 193)

Na obra de Proust, Em busca do tempo perdido, o narrador, Marcel, ao mergulhar um pedaço de doce no chá e reencontrar o sabor que lhe era tão caro na infância, é transportado ao universo da memória afetiva. Vale ressaltar o fato de que a memória recriada sob a pena de Proust não se encontra restrita a seqüências de fatos cronológicos; ao contrário, tomado por um anseio de descobrir novos sentidos, o narrador tece novas conexões e redes, redescobrindo seu passado, recriando um espaço existencial sempre tão repleto de mistérios e indagações que permite a inserção da imaginação de cada leitor em sua obra.

Saborear um alimento, desfrutar de um aroma ou ouvir uma canção como metáforas de um mergulho na memória, após Proust, tornaram-se recursos narrativos tão utilizados pela narrativa cinematográfica que passaram a incorporar a linguagem dos comerciais e até mesmo das novelas de televisão. Se, em Proust, o toque da sonata desvenda os múltiplos significados da relação entre o personagem de Swann e a cortesã Odette, pela qual ele nutre um sentimento obsessivo, nas novelas globais, as canções são programadas para caracterizar um determinado personagem, sendo depois inseridas em trilhas sonoras à venda durante o período em que a narrativa permanece no ar. 
Ao contrário das sutilezas que cada objeto desencadeador da memória revela, na obra proustiana, nas novelas ou nos filmes, muitas vezes esses momentos narrativos são utilizados como um modo de repetir cenas passadas aos novos espectadores, que, aos poucos, passam a acompanhar os capítulos de um folhetim na tela. Em jargão televisivo, esses espaços de lembranças são chamados de flashbacks, uma volta ao passado em forma de memória involuntária.

No seio do universo de Proust, contudo, conforme especifica Philippe Willemart (2000, pp. 64-5), existem laços entre o objeto provocador de lembranças e a pessoa que se recorda dos acontecimentos, como nas lendas celtas em que os entes queridos desaparecidos fazem o primeiro movimento e são reconhecidos. Mas o narrador de Proust vai além, já que esses objetos desencadeadores de lembranças, como o bolinho Madeleine mergulhado no chá, parecem não só agir como também dialogar com as personagens. A rememoração inventada por Proust é de outro gênero; ela não depende da repetição de um gesto ou um lapso, de uma neurose ou uma perversão, de um mal-estar ou uma indisposição, mas apenas de uma circunstância ou um acaso, assim como o encontro dos seres inferiores, encarnação de entes queridos nas lendas celtas.

Pois bem, lembrando que Mnemósine é a mãe de todas as musas, senhora da memória, vamos tentar estabelecer que, no caso da escritura de Em busca do tempo perdido, ela é realmente tratada como a filha de Urano, o céu, enquanto elemento fecundo, e Gaia, a Terra, elemento primordial, amante de Zeus, o deus da luz e do conhecimento, e mãe de todas as artes.

O culto à memória seria sinônimo de elegia à tradição? Optar pela memória como fator preponderante na criação seria equivalente a ressaltar a importância dos cânones na tradição literária? Para criar, bastaria mergulhar nas obras clássicas?

É nesse ponto que Proust rompe, justamente, com uma interpretação rasa do mito grego, resgatando-Ihe as nuanças e redes de significado. Pois, em sua obra, se a memória corporifica uma narrativa, utilizando fatos da terra, do universo, de sua mãe Gaia, digamos, o toque de Urano, seu pai, deus celeste do acaso e do 
imponderável, transforma esse recurso em fonte inesgotável de novas redes de significado. Swann, por exemplo, personagem querido da obra proustiana, ora é lembrado como um homem galante e amante das artes, ora como um tolo manipulado por uma cortesã vulgar. O espaço da memória proustiana, ao contrário do recurso do flashback nas narrativas das novelas, instaura-se como o lugar da dúvida, da inquietude, do engano, mas também da descoberta constante, um espaço gerador de criatividade e novas interpretações, justamente como as narrativas fecundas da própria mitologia grega.

Como tão bem define Willemart (2000, p. 199),

a escritura proustiana trouxe novos elementos para 0 conhecimento do homem, além de sugerir um modo de escrever inovador que poderia ser explicitado da seguinte forma: criar um espaço de escritura cada vez mais complexo, imitando as revoluções dos astros, voltando não necessariamente às mesmas posições, mas girando em torno de palavras ou significantes, das mesmas personagens ou situações, sem preocupação de linearidade ou cronologia, deixando à vontade um narrador que, nas revoluções, capta impressões e sensações experimentadas no decorrer da vida, transformando-as, sob a ação da inteligência, em leis gerais.

Ou ainda, conforme define o poeta Novalis (apud Willemart, 2000, p. 200), citado em seguida:

Estes seres raros e de passagem que atravessam, de tempos em tempos, os lugares de nossa estada e renovam em todo lugar o antigo e venerável culto à humanidade e a seus primeiros deuses: os astros, a primavera, o amor, a felicidade, a fecundidade, a saúde e a alegria.

Vista sob essa ótica, a memória proustiana não se apresenta como um passado que aprisiona e condiciona a escritura; ao contrário, alimento da 
sensibilidade, a recordação, esse vago testemunho em primeira pessoa, surge como tecido de sutilezas e complexidades. No lugar de impor-se como um recurso de autoridade, um testemunho daquele que viveu muito e, portanto, pode ditar regras, a imprecisa verdade que se espalha pelas dúvidas inerentes a toda lembrança acolhe a fragilidade da condição humana.

Afirma Willemart (2000, p. 216), em seu capítulo final:

A concepção de história da literatura provavelmente mudará, se levarmos em conta a contribuição proustiana à criação. Construir uma teoria literária, não mais a partir de escolas ou gêneros contextualizados historicamente, mas de personagens ou de situações simbólicas, é um desafio. Os gigantes, Pantagruel, o duque de Guermantes e convidados são um exemplo que poderia ser seguido com outras personagens ou situações diversas encenadas na literatura universal.

Ironizar e contestar a história da literatura, seus mitos, autores, cânones e também equívocos, constitui matéria criativa para o Jorge Luis Borges, cuja obra instigante abordarei em seguida. 
Capítulo 2

A Memória do Sonho 


\section{A Memória do Sonho}

Jorge Luis Borges, escritor argentino cuja obra se constitui como um percurso através dos labirintos de uma memória literária, afirmava que aos 9 anos teria testemunhado um engano: a tradução do conto "The Happy Prince", do autor Oscar Wilde, teria sido erroneamente atribuída ao seu pai. A partir dessa confusão, Borges teria começado a construir uma literatura na qual as falsas atribuições e mistificações literárias funcionam como um jogo literário, um desafio à memória erudita, já que é preciso investigar quanto à autoria "real" de seus textos. (Cotidianus, 2005)

Dentro desse espírito de jogo, Jorge Luis Borges criou um autor imaginário de contos policiais, $\mathrm{H}$. Bustos Domecq, que tem um discípulo igualmente imaginário, D. Suarez Lynch.

Desde que o acaso permitiu atribuir a seu pai a tradução de Wilde, iniciouse o fio enganoso - e criativo - da obra de Borges, a mistificação erudita, o jogo de falsas atribuições, a elaboração de textos absolutamente apócrifos, que são verdadeiras armadilhas, colocando em teste a memória literária do leitor e do crítico, jogando por terra conceitos como autoria e originalidade.

A respeito de seu trabalho de escritor, afirmou Borges:

A literatura é um fim em si, é um meio. Se vivo para a literatura, se minha vida é uma vida essencialmente literária, se vejo tudo em função da literatura... não me importa ter sido desventurado porque essa desventura também tem sua dor literária... em meu caso, escrever é um destino. (Miranda, 2005) 
Ao ser interrogado sobre a possibilidade de originalidade no ofício literário, responde Borges:

Não creio que seja possível [a originalidade]. Para começar, todos escrevemos no contexto de um idioma. De um idioma podemos pensar o que queremos, mas já é uma tradição. Se estou no idioma espanhol estou dentro da literatura espanhola e mais precisamente na literatura castelhana. Sem dúvida, pesam sobre mim tradições cujos nomes não ouvi nunca. Todo o passado está pesando sobre mim. (Miranda, 2005)

Bem, se a originalidade e a autoria plena funcionam como ilusões, cabe à memória o papel de grande musa inspiradora de uma obra. Porém, não se trata de uma memória aprisionante, rígida, limitadora, mas, sim, um manancial de sutilezas e novas combinatórias literárias. Para Borges, portanto, memória e sonho caminham lado a lado, uma vez que o sonho, no contexto de sua obra, torna-se, ao mesmo tempo, fruto da memória e gerador de múltiplas associações.

Jorge Luis Borges (1999, pp. 35-6), ao dedicar um capítulo de obra Sete noites ao tema do sonho e do pesadelo, afasta-se intencionalmente da ótica psicológica, tratando do sonho sobretudo enquanto ferramenta literária:

O exame dos sonhos oferece uma dificuldade especial, não podemos examinar os sonhos diretamente. Podemos falar da memória dos sonhos. E, possivelmente, a memória dos sonhos não corresponde diretamente aos sonhos. Um grande escritor do século dezoito, Sir Thomas Browne, acreditava que nossa memória dos sonhos é mais pobre do que a esplêndida realidade. Outros, pelo contrário, acreditam que melhoramos nossos sonhos; se pensarmos que o sonho é uma obra de ficção (e eu 
acredito que seja) possivelmente continuamos fabulando no momento em que despertamos e, depois, quando os narramos. ${ }^{1}$

Borges (1999, p. 36) prossegue em seu raciocínio citando outros autores para, por meio deles, chegar a uma afirmação que the é muito cara: "nossas memórias são superiores a nossos pensamentos". Acrescenta ainda, ao tecer conjecturas sobre a obra de Dunne, escritor inglês do século passado que, "a cada homem é dado, com o sonho, uma pequena eternidade pessoal que the permite ver seu passado recente e, talvez, seu futuro próximo"².

"O que acontece ao despertar?", indaga Borges.

"Ocorre que, como estamos habituados à vida sucessiva, damos forma narrativa a nosso sonho, porém, nosso sonho foi múltiplo e simultâneo." (Borges, 1999, p. 37)

Para esse grande autor argentino, é como se tivéssemos duas imagens de sonhos: uma tendência a considerar os sonhos como parte da vigília, idéia esta compartilhada por algumas sociedades orais, ou a proposta poética de considerar toda vigília como uma espécie de sonho.

Aliás, esse último conceito encontra-se explícito na obra do escritor chinês Chuang Tzu, cujo pensamento fundamentado na filosofia taoísta era admirado por Borges. Segue, abaixo, uma pequena fábula de Chuang Tzu que ilustra nitidamente o conceito borgiano de sonho poético:

Uma vez sonhei que era uma borboleta, flutuando feliz pelos ares!

Mas, assim que despertei, percebi que meu corpo era humano, o mesmo de sempre, forte, compacto, de carne e osso. Porém, ainda

\footnotetext{
1 "El examen de los sueños ofrece una dificultad especial. No podemos examinar los sueños directamente. Podemos hablar de la memoria de los sueños. Y posiblemente la memoria de los sueños no se corresponda directamente con los sueños."

2 "A cada hombre le está dado, con el sueño, una pequeña eternidad personal que le permite ver su pasado cercano y por ventura su porvenir cercano."
} 
totalmente tomado pelo prazer do vôo e pela sensação de liberdade das asas, pensei assim:

Será que isso foi Chuang Tzu sonhando que era uma borboleta ou a borboleta sonhando que era Chuang Tzu? (Werner, 1991)

Para Borges, essa zona intermediária entre o sonho e o seu despertar seria o espaço poético onde germina o texto ficcional.

Nesse mesmo ensaio, o autor cita ainda os sonhos proféticos, utilizados como mola propulsora da ação em textos como a obra clássica, A odisséia. Após o sonho, o desenrolar da narrativa seria prova de que o sonho foi falso ou verdadeiro.

Acrescentamos ao argumento de Borges o fato de que na obra $A$ morte de Arthur, de Thomas Mallory, os sonhos do mago Merlim apontam caminhos de destino para o rei Arthur, de modo que, sem excluírem a possibilidade de uma livre escolha, servem como pistas narrativas, incitando a curiosidade do leitor para que ele prossiga com a leitura a fim de confirmar ou não a sabedoria contida nas palavras do sábio inspirado por um mundo onírico e sobrenatural. (Prieto, 1996, p. 44)

Além do sonho de encantamento e do sonho profético, porém, a literatura é também povoada por emocionantes descrições de pesadelos, diz Borges.

Em seguida, ele analisa o termo pesadelo em diferentes idiomas: incubus, em latim, personalizaria um demônio que atormenta o sonhador; em alemão, o termo alp também corresponderia à idéia de um elfo maligno responsável pelo sonho aterrorizante. Finalmente, elege a palavra inglesa nightmare como sua preferida, uma vez que trata o sonho como uma égua da noite, um animal selvagem que leva o espírito de quem sonha numa cavalgada de intenso perigo e emoção.

A metáfora do animal e seu cavaleiro pressupõe uma interação que complementa a idéia apresentada logo no início do capítulo de que a memória do sonho contém um embrião narrativo gerador de fábulas. 
Às palavras de Borges, gostaria de acrescentar que essa passagem onírica, seja dominada pelo encanto ou pelo temor, parece gerar uma necessidade de fabular. E, para que o sonho realmente exista enquanto mistério de múltiplos significados, ele precisa ser narrado, compartilhado com um ouvinte.

Não por acaso, no meio de seu ensaio, Borges sente necessidade de narrar seus piores pesadelos, sempre envolvendo angustiantes labirintos ou espelhos absolutamente assustadores. Após descrições de poesia intrínseca, Borges (1999, p. 45) conclui que:

Dizem que os sonhos nos dão uma idéia da excelência da alma, e que neles, a alma está livre do corpo ou do lugar onde julgava sonhar. Acredita-se que a alma goza de liberdade. E Addison afirmou que, efetivamente, a alma, quando liberta do trabalho do corpo, imagina, e pode imaginar com uma facilidade que não consegue ter em vigília. Agrega todas as operações da alma (da mente, diríamos agora, agora não usamos a palavra alma), sendo que a mais difícil delas é a de inventar. Sem dúvida, no sonho inventamos de modo tão rápido que equivocamos nosso pensamento com aquilo que estamos inventando.

Sonhamos ler um livro e a verdade é que estamos inventando cada palavra desse livro, mas não nos damos conta do que estamos fazendo. Nota-se em muitos sonhos esse trabalho prévio, digamos, esse trabalho de preparação das coisas. $^{3}$

De modo que os sonhos são a matéria da qual somos feitos, conforme as palavras de Borges, referindo-se a um conceito expresso por William Shakespeare.

\footnotetext{
3 "Dice que los sueños nos dan una idea de la excelencia del alma, y que el alma está libre del cuerpo y del lugar a en jugar y sonar. Cree que el alma goza de libertad. Y Addison dice que, efectivamente, el alma, cuando está libre de la traba del cuerpo, imagina, y puede imaginar con una facilidad que no suele tener en la vigilia. Agrega que de todas las operaciones del alma (de la mente, diríamos ahora, ahora no usamos la palabra alma), la más difícil es la invención. Sin embargo, en el sueño inventamos de un modo tan rápido que equivocamos nuestro pensamiento con lo que estamos inventando. Soñamos leer un libro y la verdad es que estamos inventando cada una de las palabras del libro, pero no nos damos cuenta y lo tomamos por ajeno. He notado en muchos sueños ese trabajo previo, digamos, ese trabajo de preparación de las cosas."
} 
E, fundamentalmente, sonhos geram histórias, impregnando-as de tal maneira que toda narrativa de qualquer tempo ou lugar contém fios oníricos, os quais, dependendo do foco do narrador, podem estar mais ou menos evidentes.

Ao fim de seu ensaio, Borges (1999, p. 53) deriva algumas conclusões:

A primeira é que os sonhos são uma obra estética, talvez a expressão estética mais antiga. Toma uma forma extremamente dramática, já que somos, como disse Addison, o teatro, o espectador, os atores, a fábula. A segunda se refere ao horror dos pesadelos. Nossa vigília contém momentos terríveis em abundância: todos sabemos que existem momentos em que a realidade nos soterra. Quando morre uma pessoa querida, quando uma pessoa querida nos abandona, são tantos os motivos para a tristeza e desespero...

Sem dúvida, esses motivos não se parecem com um pesadelo; o pesadelo contém um horror peculiar e esse horror peculiar pode expressar-se mediante qualquer fábula. ${ }^{4}$

Pois bem, se os sonhos são a expressão estética mais arcaica, situando a sensibilidade no limiar imemorial entre vigília e despertar, podemos considerá-los como brechas catalisadoras, cujos conteúdos, latentes ou expressos, fogem ao controle daquilo que a cultura opta por conservar.

A memória e o esquecimento, em termos culturais, e o controle exercido pelos cânones, instrumentos da conservação de textos eleitos como "clássicos", segundo a concepção de luri Lotman, serão o próximo tópico abordado.

4 "La primera es que los sueños son una obra estética, quizá la expresión estética mas antigua. Toma una forma extrañamente dramática, ya que somos, como dijo Addison, el teatro, el espectador, los actores, la fábula." 
Capítulo 3

A Memória da Cultura 


\section{A Memória da Cultura}

Em sua bela obra, Os prazeres e os dias, Proust dedica um capítulo ao tema do sonho. Descrito em tom confessional, há o relato do encontro entre o narrador e uma jovem, Dorothy B..., personagem insípida, totalmente desprovida de charme ou sensibilidade. Curiosamente, por razões inexplicáveis, essa mesma dama ressurge em ambiente onírico, povoando um sonho com uma atmosfera de delicado erotismo. Resultado: o narrador desperta totalmente apaixonado, e afirma:

Dorothy $B$... cessara de ser para mim a mulher que fora na véspera. [...] Eu sentia um desejo imenso, desencantado por antecedência, de revê-la, a necessidade instintiva e sábia desconfiança de lhe escrever. Seu nome, pronunciado numa conversa, me fazia estremecer, evocando, no entanto, a imagem insignificante que sempre a acompanhara antes daquela noite, no tempo em que me fora indiferente até então. [...] A cada hora que passa, apaga-se um pouco a lembrança do sonho já bem desfigurado por esse texto. Eu o vejo cada vez mais como se fosse um livro que se deseja continuar a ler quando anoitece e não há luminosidade suficiente. Para percebê-lo ainda mais um pouco, sou obrigado a parar de pensar nele por um instante, como se é obrigado a fechar os olhos para tentar ler um pouco mais um livro já coberto pelas sombras. [...] Porém, sei que reencontrarei Mme B... sem nenhuma emoção. De que adiantaria lhe contar de coisas das quais ela se mantém tão distante?

Vejam! O amor passou por mim como este sonho, com um poder transfigurador igualmente misterioso. Assim, vocês que conhecem a mulher 
que amo e que não estavam no sonho jamais compreenderão; portanto, nem sequer tentem me entender. ${ }^{5}$ (Proust, 1924, pp. 242-3)

Conforme as palavras de Borges, citadas no Capítulo 2, os sonhos se apresentariam como uma obra estética, talvez a ficção mais antiga da espécie humana. O que interessa nesse breve trecho da prosa proustiana não é o sonho em si, mas a memória dele, infinitamente mais plena de significados e prazeres do que a realidade de um encontro amoroso entre o narrador e o objeto de sua paixão.

Ironizando o próprio texto, o narrador afirma que a descrição que faz do ambiente onírico está muito aquém dos sentimentos desfrutados por ele enquanto sonhador. E prossegue, afirmando que precisa preservar a memória daquele momento que se desfaz rapidamente, como as páginas de um livro que, aos poucos, são cobertas por sombras ao entardecer. É como se o sonho fugisse ao controle, instaurando uma outra dimensão de realidade, tênue, ambígua, matéria mágica do entardecer, o momento do encontro entre os mundos reais e imaginários, segundo as lendas celtas, citadas por Marcel em A busca do tempo perdido.

Tornado inesquecível pelo texto proustiano, o sonho, mesmo desfigurado, infiltra-se na realidade literária habitada por Marcel, transformando uma jovem vulgar em personagem imemorial. É como se, ao compartilhar de um breve entusiasmo por uma mulher sem importância com o leitor, o narrador inscrevesse sua fina

${ }^{5}$ « Dorothy B... avait cesse d'être pour moi la femme qu'elle était encore la veille. Le petit sillon laissé dans mon souvenir para les quelques relations que j'avaia eues avec elle étais presque effacé, comme aprés une marée puissante qui avait laissé derriére elle, en se retirant, des vestiges inconnus. J'avais um immense désir, désenchanté d'avance, de la revoir, le besoin instinctif et la sage défiance de lui écrire. Son nom prononcé dans une conversation me fit tresaillir, évoqua pourtant l'image insignifiante qui l'eût seule accompagné avant cette nuit, et pendant qu'elle m'était indifférente comme n'importe quelle banale femme du monde, elle m'attirait plus irresistiblement que les maîtresses les plus chères, ou la plus enivrante destine. Je n'aurais pás fait um pas pour la voir, et pour l'autre "elle", j'aurais donné ma vie. Chaque heure efface um peu le souvenir du revê déjà bien defiguré dans ce récit. Je le distingue de moins en moins, comme um livre qu'on veut continuer à lire à sa table quand le jour baissant ne l'éclaire plus assez, quand la nuit vient. Pour l'apercevoir encore um peu, je suis obligé de cesser d'y penser par instants, comme on est obligé de fermer d'abord les yeux pour lire encore quelques caracteres dans le livre plein d'ombre. Tout effacé qu'il est, il laisse encore um grand trouble en moi, l'écume de son sillage ou la volupté de son parfum. Mais ce trouble lui-même s'evanouira, et je verrai Mme B... sans émotion. A quoi bom d'ailleurs lui parler de ces choses auxquelles elle est restée étrangére? Helás! L'amour a passe sour moi comme ce revê, avec une puissance de transfiguration aussi mystérieuse. Aussi vous qui connaissez celle que j'aime, et qui n'étiez pas dans mon revê, vouz ne pouvez pas me compreendre, n'essayez pas de me conseiller. » 
sensibilidade nos anais da memória coletiva, perguntando-lhe francamente: quem jamais se apaixonou por uma mulher indigna?

E o que seria matéria dessa memória coletiva? A lembrança do erro? Do sonho? Da perda da ilusão?

Em sua obra Armadilhas da memória, Jerusa Pires Ferreira (2004, pp. 6972) elege o semioticista luri Lotman como uma "unanimidade", um pensador cuja obra merece admiração e respeito incondicionais. E afirma a tese central de Lotman segundo a qual seria possível

adotar, a priori, como quadro de classificação dos códigos da cultura, sua relação do signo aos signos e aos sistemas de signos - e que a sucessão de códigos dominantes da cultura será, ao mesmo tempo, uma penetração, cada vez mais profunda, da consciência cultural coletiva, nos princípios que regem os sistemas de signos.

A memória da coletividade é definida, portanto, como o "acompanhamento de como a experiência da vida do gênero humano se faz cultura" (Lotman, 1996, p. 73). De modo que cada artista, conforme afirma Cecilia Almeida Salles, em seu livro Gesto inacabado (p. 27), estaria "imerso e sobre-determinado pela sua cultura, (que por seu estado de efervescência possibilita o encontro de brechas para a manifestação de desvios inovadores) e dialogando com outras culturas, está o artista em criação".

Ao interagir com seu meio, o artista atuaria como um multiplicador de conexões. Pois, conforme afirma Lotman (1996, pp. 74-5),

a cultura não é um depósito de informações; é um mecanismo organizado, de modo extremamente complexo, que conserva as informações, elaborando continuamente os procedimentos mais vantajosos e compatíveis. 
Recebe as coisas novas, codifica e decodifica mensagens, traduzindo-as para um outro sistema de signos.

Desenvolvendo um raciocínio a partir do conceito acima, Jerusa Pires Ferreira considera que transformar a realidade em texto para ser inserida em memória coletiva trata-se de um ponto fundamental. A cultura seria então um processo de coleta de informação, codificação desse material, transmissão, memória. "Somente aquilo que foi traduzido num sistema de signos pode vir a ser patrimônio da memória", são as palavras de Lotman (1996, p. 75), que, ao estudar a memória à luz da cultura, declara:

Do ponto de vista da semiótica, a cultura é uma inteligência coletiva e uma memória coletiva, isto é, um mecanismo supraindividual de conservação e transmissão de certos comunicados (textos) e da elaboração de novos. Nesse sentido, o espaço da cultura pode ser definido como um espaço de certa memória comum, isto é, um espaço dentro de cujos limites alguns textos comuns podem conservar-se e ser atualizados. A atualização desses mesmos se realiza dentro dos limites de algum invariante de sentido que permite determinar em que contexto da nova época o texto conserva, com toda a variância de interpretações, a qualidade de ser idêntico a si mesmo. Assim, a memória comum para o espaço de uma cultura dada é assegurada, em primeiro lugar, pela presença de alguns textos constantes e, em segundo lugar, por uma unidade de códigos ou por sua invariância, ou pelo caráter interrompido e regular de sua transformação. ${ }^{6}$

6 "Desde el punto de vista de la semiótica, la cultura es una inteligencia y una memoria colectiva, esto es, un mecanismo supraindividual de conservación e transmisión de ciertos comunicados (textos) y de la elaboración de otros nuevos. En este sentido, el espacio de la cultura puede ser definido como un espacio de cierta memoria común, esto es, un espacio dentro de cuyos limites algunos textos comunes pueden conservarse y ser actualizados. La actualización de estos se realiza dentro dos limites de alguna invariante de sentido que permite decir que en el contexto de la nueva época el texto conserva, con toda la varianza de las interpretaciones, la cualidad de ser idéntico a si mismo. Así pues, la memoria común para el espacio de una cultura dada es asegurada, en primer lugar, por la presencia de algunos textos constantes, y, en segundo lugar, o por la unidad de los códigos, o por su invarianza, o por el carácter ininterrumpido y regular de su transformación." 
Jerusa Pires Ferreira (2004, p. 76) ressalta o fato de que para Lotman

a Cultura, em essência, se dirige contra o esquecimento. Seu pensamento parece estar muitas vezes partindo de uma dialética, que, aliás, tem preocupado muitos pensadores da Cultura e da Arte; a memória e sua contrapartida, o esquecimento. Entram em consideração os barradores, seja aquilo que bloqueia, também os elementos que propiciam a lembrança, os vários tipos de lembrança, as estratégias e os impasses que geram o esquecimento. Assim, Freud, Lacan, Lévi-Strauss, Vernant, Zumthor, cada um a seu modo, trouxeram importantes contribuições.

Jerusa Pires Ferreira ressalta, com propriedade, a importância de fazer uma distinção entre a longevidade dos textos na memória coletiva e dos códigos na memória seletiva das comunidades. Memória e tradição, portanto, não seriam sinônimos, já que uma determinada tradição pode optar por excluir textos da memória coletiva que não sejam convenientes ou compatíveis com os conteúdos que deseja preservar.

Nesse sentido, as palavras de Willemart, citadas ao término do Capítulo 1, são bastante apropriadas ao ressaltar que a obra de Proust passa a evidenciar a necessidade da construção de uma teoria literária "não mais a partir de escolas ou gêneros contextualizados historicamente, mas de personagens ou de situações simbólicas" (Willemart, 2000, p. 216). Ou seja, ao artista caberia a escuta das camadas culturais que o coletivo tende a excluir.

Segundo essa ótica, podemos aventar a hipótese de que o artista ocuparia o lugar de guardião de uma sensibilidade ancestral, a ficção primordial, impregnada pelo elemento onírico, testemunha do acaso e do imponderável, das brechas imprevisíveis, das verdades que escapam ao controle da cultura oficial através dos tempos e lugares. A partir dessa outra concepção de história da literatura, livre dos grilhões impostos por cânones, estaríamos abrindo espaço para a dinâmica recriadora, conforme definição de Jerusa Pires Ferreira (2004, p. 81), que, citando Lotman, ressalta o fato de que 
a cultura não se contrapõe ao caos, mas a um sistema de signos oposto. Ou seja, num texto irão trabalhar dois mecanismos: um deles servirá para manter na consciência do receptor ou do auditório a memória de certa organização tradicional do texto, fornecendo-lhe com isso alguma estrutura esperada; o outro irá destruir essa estrutura, dessemantizando a percepção e constituindo o individual.

Escolhas artísticas inusitadas, preservação daquilo que foi eleito, coletivamente, para ser relegado ao esquecimento geral, diálogos frutíferos com a memória cultural, rebeldia com relação a cânones, todas essas são características do gesto criador do artista, tema central do próximo capítulo. 
Capítulo 4

A Memória do Gesto Criador 
Discutir arte sob o ponto de vista de seu movimento criador é acreditar que a obra consiste em uma cadeia infinita de agregação de idéias, isto é, em uma série infinita de aproximações para atingi-la [...]. Arte não é só o produto considerado acabado pelo artista: o público não tem idéia de quanta esplêndida arte perde por não assistir aos ensaios [...]. O artefato que chega às prateleiras das livrarias, às exposições ou aos palcos surge como resultado de um longo percurso de dúvidas, ajustes, certezas, acertos e aproximações. Não só o resultado, mas todo esse caminho para se chegar a ele, é parte da verdade [...] que a obra carrega. Cecilia Almeida Salles, Gesto inacabado. 


\section{A Memória do Gesto Criador}

Há todo "um vasto elenco" de estudos de crítica genética desenvolvidos na PUC de São Paulo, sob a coordenação de Cecilia Almeida Salles. Conforme indaga Philippe Willemart, em sua obra Crítica genética e psicanálise (p. 4), "será que assistimos ao 'nascimento de uma nova ciência' ou mais simplesmente à criação de laços novos com a 'realidade'?".

Willemart prossegue em seu raciocínio, afirmando que a crítica genética teria deslocado o olhar do pesquisador do produto acabado, para o processo que incluiria esse produto considerado como uma das versões. Não é somente um deslocamento, que implica ficar na mesma superfície, mas, antes, um distanciamento por cima, que exige, como dizia o narrador proustiano, "um telescópio para distinguir coisas efetivamente muito pequenas, mas porque situadas a longas distâncias, cada uma num mundo". (Willemart, 2005, p. 5)

Em sua obra sobre o processo de criação artística, intitulada Gesto inacabado, Cecilia Almeida Salles aponta para o fato de que cada artista está inserido num projeto poético pessoal. Afirma que,

em toda prática criadora, há fios condutores relacionados à produção de uma obra específica que, por sua vez, atam a obra daquele criador, como um todo. São princípios envoltos pela aura da singularidade do artista [...] gostos e crenças que regem o seu modo de ação: um projeto pessoal, singular e único. (Almeida Salles, 2004, p. 41)

Contudo, embora ressalte a especificidade de cada obra, a pesquisadora complementa: "esse projeto estético, de caráter individual, está localizado em um 
espaço e um tempo que inevitavelmente afetam o artista" (Almeida Salles, 2004, p. 37).

Não se deve confundir a afirmação de Salles com uma concepção simplista, segundo a qual o artista seria apenas o fruto de seu meio e de seu tempo. Mas, sim, de uma espécie de diálogo polifônico, sutil, que a obra em criação estabelece com a época em que é gerada e com a rede de criação da qual faz surgir uma multiplicidade de novas conexões. Ou seja, há o olhar único e intransferível, mas existe também o objeto desse mesmo olhar e tudo o que ele carrega enquanto elemento gerador de novos significados.

Afirma Cecilia Almeida Salles (2004, p. 38):

O artista não é, sob esse ponto de vista, um ser isolado, mas alguém inserido e afetado pelo seu tempo e seus contemporâneos. O tempo e o espaço do objeto em criação são únicos e singulares e surgem de características que o artista vai Ihes oferecendo, porém se alimentam do tempo e espaço que envolvem sua produção. Bakhtin [...] afirma que "as grandes descobertas do gênio humano só são possíveis em condições determinadas de épocas determinadas, mas elas nunca se extinguem nem se desvalorizam juntamente com as épocas que as geraram".

Conforme vimos, porém, ao acompanharmos o pensamento de Lotman, a cultura estabelece uma relação dinâmica com a memória, de modo que é como se cada época elegesse determinados repertórios do passado para com eles tecer um diálogo que não só os ressignifica como também alimenta a produção artística num dado momento.

É nesse sentido que a obra de um autor do século passado, como a do argentino Jorge Luis Borges, ao escolher a utilização de pseudônimo, ou os textos apócrifos de diferentes religiões como objeto gerador de novos textos, imprime novas nuanças à ousadia da escrita de Chuang Tzu, sábio taoísta cujos aforismos parecem abrigar várias camadas de significado. 
Lendo Borges, fica difícil delimitar o que é de autoria dele, ou o que foi simplesmente acrescentado como mero jogo literário. Se Borges considera toda ficção como uma forma de sonho e vice-versa, a imprecisão da memória do sonho é o território onde sua obra é gerada, um sonho que contém vários capítulos da história da literatura mundial, diga-se de passagem.

Ora, se considerarmos, conforme afirma Lotman, que a contrapartida da memória é o esquecimento, é possível pressupor toda uma infinita cadeia de falsas suposições. Quer dizer, da mesma maneira pela qual certos autores podem ser eleitos como clássicos dentro de um determinado contexto cultural, pelas razões mais diversas, os mitos que se tecem em torno do processo criador da obra desse mesmo autor eleito podem estar muito impregnados de "esquecimentos culturais" de natureza profundamente subjetiva. Daí, a verdade literária que emana do jogo textual nitidamente falso que Borges estabelece com relação a mitos como autoria, memória e cânones de um modo geral.

Mais importante do que o cânone, esse mecanismo de escolha e atribuição de notoriedade que contém vários pontos em comum com a prática de qualquer esporte ocidental, pressupondo a presença de obras eleitas ou campeãs, seria a rede de trocas e diálogos artísticos, expandindo-se e transformando-se ao longo dos tempos.

Em obra recente, intitulada justamente Redes da criação, Cecilia Almeida Salles amplia o estudo sobre a dinâmica do artista em seu diálogo com sua época e a escolha entre os vários passados que um mesmo presente sempre contém. Focalizada desse ângulo, podemos considerar a memória como um agente criador em ação, "vista nessa perspectiva da mobilidade: não como um local de armazenamento de informações, mas um processo dinâmico que se modifica com o tempo" (Almeida Salles, 2006, p. 30). Este enfoque, na verdade, reforça suas afirmações anteriores, feitas em Gesto inacabado (Almeida Salles, 2004, p. 38).

Tal concepção da memória afasta-se da idéia positivista e simplista de que a obra é apenas fruto de um tempo e espaço. Sim, a criação contém as marcas de seu lugar de origem e tempo histórico, porém traz consigo, sobretudo, a relação 
geradora de novos significados que um artista estabelece com seu meio, sua tradição, sua memória pessoal. O narrador proustiano difere de Marcel Proust, cidadão francês; os acontecimentos narrados na obra Em busca do tempo perdido são ficcionalizados e o próprio trajeto da memória que o narrador se empenha em resgatar insere-se em determinada ação poética, escolhida como o melhor veículo para a sensibilidade literária do narrador.

Da mesma forma, os lapsos de memória, a incerteza das fronteiras entre sonho e realidade, são propositalmente ressaltados na obra de Borges, cuja intenção declarada é capturar o encantamento e sabedoria que impregnam as zonas intermediárias do saber, as brechas da sensibilidade, a imprecisão da própria existência humana, como bem descreve o poema da borboleta do sábio chinês citado no Capítulo 2, escolha acertada de Borges para funcionar como metáfora do conhecimento literário.

"A criação alimenta-se e troca informações com seu entorno em sentido bastante amplo. Estamos dando destaque, desse modo, aos aspectos comunicativos da criação artística." (Almeida Salles, 2006, p. 41)

Tal raciocínio prossegue, exemplificando ainda:

Volto à imagem de rede para compreender como o artista se envolve com a cultura, isto é, os diálogos que ele estabelece se interconectam em uma trama que o insere em determinadas vertentes ou linhagens. Daí a relevância de se acompanhar as escolhas responsáveis pela formação dessa trama. É assim que vamos compreender a relação do artista com a tradição. Cada obra ou cada manuseio de determinada matéria estabelece diálogos com a história da arte, da ciência e da cultura de uma maneira geral, assim como se remete ao futuro. Em jogos interativos, o artista e sua obra alimentam-se de tudo que os envolvem e indiciam algumas escolhas. (Almeida Salles, 2006, p. 42) 
A tradição, do ponto de vista de Cecilia Almeida Salles não seria, portanto, uma constante sólida, imutável, mas como no caso da memória criativa, na qual cada vertente possibilitaria vários trajetos possíveis.

Em se tratando da obra Em busca do tempo perdido, segundo estudos de Pierre-Louis Rey e Brian G. Rogers (1990, p. XXI), Proust teria estabelecido um diálogo com o clássico oriental, As mil e uma noites. Intrigas, suspense, sonhos e imaginação, compostos em sobreposição, regados por uma lucidez melancólica, geraram essa obra noturna na qual Marcel, o narrador, seduz o leitor constantemente, de modo que ele sempre volte a retomar o extenso caminho que desvenda o universo proustiano.

Obra passível de diversas leituras, Em busca do tempo perdido impede o rompimento do pacto da narrativa das histórias e seria nesse sentido, justamente, que seu narrador pode ser comparado a Sherazade. O silêncio da voz, o livro que se abandona, correspondendo à morte da paixão literária.

Na verdade, a obra conhecida como As mil e uma noites seria, ela mesma, fruto de uma outra tradição de histórias de ensinamento e encantamento, conforme veremos no próximo capítulo. 
Capítulo 5

A Memória da Voz 
Uma jovem, conhecida por sua vasta cultura e inteligência, roga ao pai, o vizir, que Ihe permita casar-se com o sultão, apesar de saber que, após a noite de núpcias, seu destino seria a morte. Não se deixa demover pelos apelos ou avisos do pai para que desista de tão louca empreitada. Mostrando a mais completa serenidade, assegura-lhe que não deve temer por sua vida, e que ela não pode furtar-se ao dever de tentar salvar as filhas dos muçulmanos da triste sorte que as aguarda.

Sabemos que o sultão se transformara em homicida sanguinário após uma grande desilusão: a esposa o traíra com o mais reles dos escravos. Tudo nos leva a pensar

tratar-se de um caso de doença psicogênica após a ocorrência de um trauma.

Purificación Barcia Gomes, O método terapêutico de Scheerazade. 


\section{A Memória da Voz}

Costumes e crenças da sociedade islâmica surgem como pontes para a reflexão sobre a psicanálise e a literatura na obra de Purificación Barcia Gomes, $O$ método terapêutico de Scheerazade: mil e uma histórias de loucura, desejo e cura. Sobre esse trabalho, afirma o psicanalista Renato Mezan:

Alicerçada num sólido conhecimento da literatura de ficção, das teorias literárias contemporâneas e dos escritos psicanalíticos, [a autora] focaliza os vários tipos de narrativa - pois os dados clínicos também surgem para nós a partir de uma narrativa, a que o paciente faz de si e de sua vida. (In: Barcia Gomes, 2000, texto de orelha)

Pois bem, já de início, a autora nos alerta no sentido de que não façamos uma leitura equivocada do papel da narradora Sherazade, a famosa tecelã das noites:

Segundo as regras vigentes no mundo mágico do Oriente, o soberano teria a prerrogativa de cometer qualquer atrocidade que the apetecesse. Por isso, a tarefa de Scheerazade não parece ser, à primeira vista, a de corrigir um comportamento desviante ou aberrante do sultão Shariyar; não é uma educadora, nem uma reformadora social. Sua atividade se nos afigura como propriamente terapêutica: o sultão sofre, e através dos encontros com Scheerazade, esta Ihe diz coisas que aliviam o seu sofrimento. (Barcia Gomes, 2000, p. 14) 
A autora prossegue em sua exposição, fazendo ainda mais uma ressalva de extrema importância:

Admitamos, pelo momento, como fizeram entre outros Borges e Benjamin, que Scheerazade era uma competente terapeuta: seria tentador perguntar se seu método e sua técnica teriam algo a ver com a psicanálise. À primeira vista, ficaríamos tentados a dizer que não. Para começar, ela percorre um trajeto oposto ao fundador da psicanálise e ao de seus seguidores. Frente ao trauma, Freud escuta as associações livres do paciente: Scheerazade põe-se a falar por longas mil e uma noites. O sultão, o suposto paciente, só se faz ouvir em raras ocasiões. Também não parece provável que ela tenha utilizado a noção de inconsciente, ou ainda que tenha feito alguma interpretação mais formal do sultão. No tocante à neutralidade analítica, nada menos neutro do que sua conduta: satisfazia o sultão de várias maneiras, inclusive sexualmente. (Barcia Gomes, 2000, p. 14)

Haveria um método? Uma intencionalidade na maneira de narrar e entremear as histórias?

Ao iniciar seu estudo, Barcia Gomes cita novamente Borges, ressaltando a importância dessa obra: "As mil e uma noites não são uma coisa morta. Trata-se de um livro tão vasto que nem é preciso lê-lo. Ele é parte prévia de nossa memória". (Barcia Gomes, 2000, p. 15)

De acordo com a premissa citada anteriormente, de que seria preciso situar a função do narrador no mundo islâmico, de modo a ter uma visada mais concreta do papel das narrativas, Barcia Gomes, recorrendo a Borges, nos instrui no sentido de que na Pérsia o entretenimento noturno do jovem rei Alexandre Magno era ouvir fábulas contadas por homens especializados em contar histórias, os confabulatores nocturni. E acrescenta: 
Mais recentemente, falando dos primeiros séculos da fundação do Islã, o arabista Irwin lembra que se atribuem duas origens prováveis à tradição oral no Oriente: uma religiosa e outra secular. A religiosa refere-se à existência de pregadores e comentadores do Corão: os khatib, pregadores propriamente ditos, e os quassas, contadores de histórias religiosas, nem sempre ortodoxas, os quais, por essa razão, acabaram sendo expulsos das mesquitas e criaram os textos islâmicos apócrifos (constituídos de fábulas sobre profetas pré-islâmicos). Finalmente se instalaram nas ruas, bazares e cemitérios como contadores populares de ditos anedóticos, supostamente religiosos, a troco de moedas. (Barcia Gomes, 2000, p. 16)

Barcia Gomes estabelece uma comparação entre a relação ouvinte e contador de histórias, paciente e analista, no sentido de que ambas necessitam permanecer dentro de um pacto. Caso o analista lide, por meio da escuta, com uma ferida emocional de forma inadequada, haverá o afastamento do paciente, da mesma maneira como um contador de histórias não pode permitir uma má escolha de narrativa, cujo conteúdo, de algum modo, provoque a desatenção do ouvinte. Em ambos os casos, o equívoco resulta na quebra do pacto e esfacelamento da relação. Há sempre o risco iminente de morte da relação, tanto numa situação quanto na outra.

Gostaria de acrescentar que o mesmo risco corre o escritor. Caso o texto perca seu interesse para o leitor, ele fecha o livro e o abandona, o que, no espaço da literatura, significaria o rompimento do pacto entre leitor e obra.

Após suas considerações, Barcia Gomes (2000, p. 18) regressa

aos colegas anônimos de Scheerazade, afirmando que, após a conquista otomana, no começo do século XVI, os contadores de histórias, assim como os demais artífices e trabalhadores, são obrigados a fazer parte de guildas, e passam a trabalhar em cafés, uma nova instituição social que surge nessa época, e que é bastante malvista pela sociedade honesta e trabalhadora. Alguns desses homens conseguem atrair de tal forma a atenção 
da audiência, que chegam a ser objetos de cronistas do Ocidente, admirados com seu poder de sedução [...]. A técnica utilizada pelos narradores árabes se assemelha à de Scheerazade: interromper sua narrativa a cada noite, ou seja, aguçar a curiosidade do ouvinte através da amplificação do suspense.

É importante observar que a técnica da interrupção da narrativa seria utilizada por autores como Alexandre Dumas, apelidado de Scheerazade, tal seu amor pela personagem das Mil e uma noites (Maurois, 1993, p. 1.058). Em função do formato folhetim, no início do império jornalístico, Dumas instaura o suspense na maneira de narrar as peripécias de seus Três mosqueteiros. Eventualmente, com o advento do cinema, essa mesma técnica seria utilizada para manter desperta a atenção do espectador. A interrupção da narrativa em momento culminante seria, em jargão cinematográfico, "o ponto de virada". A televisão também utiliza o mesmo recurso, tanto nas novelas brasileiras como nos seriados norte-americanos, prolongando, por muitas noites, o pacto entre espectador e filme.

Poucos estudos teóricos, porém, contemplam essa herança ou tentam rastrear as técnicas narrativas que viajam através dos tempos e lugares. 0 esquecimento cultural, fruto de uma espécie de culto ao contemporâneo naquilo que ele apresenta de mais superficial e imediato, priva a memória coletiva de reflexões mais profundas, negando elos e heranças de grande importância.

Voltando ao estudo de Barcia Gomes, vale citá-la quando se refere à necessidade que o ser humano tem das histórias:

Uma vez que estamos falando de uma necessidade de ouvir histórias, de uma necessidade de contar histórias, de uma necessidade de completar histórias, enfim, da arte de narrar e finalizar a narrativa como sendo expressão de um desejo humano, convém retomar rapidamente a questão levantada por Lagache, em contraposição às últimas afirmações de Freud, no sentido de explicar a tendência humana a repetir (que se encontraria maximizada tanto no fenômeno transferencial quanto na compulsão à repetição). De acordo com Lagache, para dar conta do fenômeno não seria 
preciso recorrer ao inatismo: basta pensar que a repetição se instala quando alguma experiência não foi suficientemente satisfatória para o indivíduo, isto é, quando alguma necessidade dele não pôde ser devidamente atendida. Ocorreria antes a repetição da necessidade, e não a necessidade de repetição. (Barcia Gomes, 2000, p. 20)

Nesse sentido, acrescenta Barcia Gomes, a narrativa dos antigos contadores de história árabes, interrompida e retomada, teria o poder de, artificialmente, criar a necessidade de mais narrativas, narrativas estas que se estabeleceriam um diálogo com outras, pessoais, de histórias de vida, no ouvinte.

Ela acrescenta sobre a importância da memorização como fonte de inspiração:

É curioso notar que, diferente da Tora, que foi revelada em uma única sessão, o Corão foi sendo revelado ao Profeta (Maomé) pouco a pouco, em doses homeopáticas, linha por linha, verso por verso, em um período de vinte e três anos, para que ele tivesse tempo de digerir e elaborar o sentido revelado. [...] Apenas para sumariar o que dissemos acima, As mil e uma noites, com seu ritmo peculiar de interrupções e retomadas, parece fazer parte de um modo árabe de revelação da verdade e de transferência de conhecimento, que transcende em muito o mero recurso estilístico. (Barcia Gomes, 2000, p. 21)

"Guardiões da palavra-emoção", esta é a bela definição poética que Barcia Gomes empresta aos contadores de histórias do mundo antigo.

Esses guardiões da palavra-emoção, da palavra memória, eram inicialmente, no mundo árabe, homens e profissionais. Com o passar do tempo, essa atividade vai sendo assumida por amadores e por mulheres, que 
contam histórias às outras mulheres e às crianças. (Barcia Gomes, 2000, p. 23)

Afirmava Walter Benjamin que narrar corresponde a aconselhar, no sentido de introduzir palavras poéticas de sabedoria. A narrativa seria então uma forma de enraizamento na própria comunidade, comunhão com a natureza, inserção numa linha de gerações passadas e futuras.

[O narrador é aquele que] sabe dar conselhos: não para alguns casos, como o provérbio, mas para muitos casos, como o sábio. Pois pode recorrer ao acervo de toda uma vida (uma vida que não inclui apenas a própria experiência, mas em grande parte a experiência alheia. O narrador assimila à sua substância mais íntima aquilo que sabe por ouvir dizer). Seu dom é poder contar sua vida; sua dignidade é contá-la inteira. O narrador é o homem que poderia deixar a luz tênue de sua narração consumir completamente a mecha de sua vida. (Barcia Gomes, 2000, p. 24)

Aprofundando a reflexão sobre o método narrativo de Scheerazade, Barcia Gomes (2000, p. 29) cita o trabalho de Adélia Bezerra de Menezes, intitulado Sherazade ou do poder da palavra, segundo o qual a capacidade de cura da tecelã das noites residiria em sua habilidade para lidar com a "necessidade primordial de ficção que habita o coração de cada homem".

Em seguida, viriam as qualidades narrativas de suas histórias, que abarcariam na maneira de contá-las, a arte do poeta, do xamã, do psicanalista:

Três especialistas, cada um em seu campo, em seu tempo, forneceriam ao doente uma linguagem, ou seja, a capacidade de propiciar uma transformação interior, consistindo numa reorganização estrutural da realidade, segundo a conhecida leitura feita por Lévi-Strauss da atividade xamanística como acesso ao discurso simbólico. [...] Poderíamos pensar a 
literatura oral ou escrita como a arte de fazer sonhar, a cujo prazer os homens se entregariam sem peias. Ocorre, porém, que o sultão acorda sozinho, repentinamente curado. Scheerazade não o interrompe nos sonhos, apenas esgota sua necessidade de sonhar. (Barcia Gomes, 2000, p. 29)

Se retomarmos, sob essa ótica, as palavras de Borges citadas no Capitulo 2, a saber:

O exame dos sonhos oferece uma dificuldade especial, não podemos examinar os sonhos diretamente. Podemos falar da memória dos sonhos. E, possivelmente, a memória dos sonhos não corresponde diretamente aos sonhos. Um grande escritor do século dezoito, Sir Thomas Browne, acreditava que nossa memória dos sonhos é mais pobre do que a esplêndida realidade. Outros, pelo contrário, acreditam que melhoramos nossos sonhos; se pensarmos que o sonho é uma obra de ficção (e eu acredito que seja) possivelmente continuamos fabulando no momento em que despertamos e, depois, quando os narramos. ${ }^{7}$ (Borges, 1999, p. 38)

talvez possamos concluir que a sabedoria do príncipe aflore porque ele resgata a capacidade de narrar, e se o sonho é o elemento gerador da ficção mais primordial, Shariyar, de algum modo, estaria recuperando o contato com a própria memória, não só individual quanto coletiva.

Esta mesma idéia da necessidade de reintegrar-se ao patrimônio cultural é mais amplamente desenvolvida por Barcia Gomes, quando afirma:

Desse ponto de vista, a narrativa de Sherazade talvez tenha o condão de lançar Shariyar a um lugar psíquico mais radical do que a simples identificação com o fato mais banal da traição e do subseqüente perdão: o

7 "El examen de los sueños ofrece una dificultad especial. No podemos examinar los sueños directamente. Podemos hablar de la memoria de los sueños. Y posiblemente la memoria de los sueños no se corresponda directamente con los sueños." 
lugar das paixões humanas, da força do desejo, do demoníaco, como o chamou Freud quando se deu conta de sua inexorabilidade, de seu caráter de repetição e intrusão. [...] Ela não é uma simples improvisadora de histórias, mas de que suas histórias se ancoram no coletivo e ela apenas é porta-voz desse patrimônio. Paradoxalmente, certo é também que Scheerazade surpreende ao mostrar-se solidária com o sultão no sentido das enormes dificuldades que essa inserção na cultura implica. (Barcia Gomes, 2000, p. 143)

Seria interessante acrescentar o fato de que a tecelã das noites não se intimida com o poder de vida e morte do sultão, nem com sua incapacidade de dormir e, portanto, sonhar. Deslocando-o do lugar da onipotência absoluta, acolhe-o no espaço falho e doloroso compartilhado por todos nós: a dor intrínseca da condição humana.

Talvez resida justamente aí a capacidade reparadora da literatura de um modo geral: o despertar primordial para a aceitação da passagem do tempo, como na obra de Proust, da impermanência, como nos aforismos de Chuang Tzu, da incerteza, como nos escritos de Borges, mas também do humor, aventura e encantamento, como no caso da obra deste outro grande herdeiro das Mil e uma noites: Alexandre Dumas. 
Capítulo 6

Narrativas Imemoriais 
Vindo desde as suas origens em distantes montanhas, após passar por inúmeros acidentes de terreno nas regiões campestres, um rio finalmente alcançou as areias do deserto. $E$ do mesmo modo como vencera as outras barreiras, o rio tentou atravessar esta agora, mas se deu conta de que suas águas mal tocavam a areia e nela desapareciam.

Estava convicto, no entanto, de que fazia parte de seu destino cruzar aquele deserto, embora não visse como fazê-lo. Então, uma voz misteriosa, saída do próprio deserto arenoso, sussurrou: - O vento cruza o deserto, o mesmo pode fazer o rio.

O rio objetou estar se arremessando contra as areias, sendo assim absorvido, enquanto [...] o vento podia voar, conseguindo dessa maneira atravessar o deserto. - Arrojando-se com violência como vem fazendo não conseguirá cruzá-lo. Assim desaparecerá ou se transformará num pântano. Deve permitir que o vento o conduza a seu destino. - Mas como isso pode acontecer? - Consentindo em ser absorvido pelo vento.

Tal sugestão não era aceitável para o rio. Afinal de contas, ele nunca fora absorvido até então. Não desejava perder a sua individualidade. Uma vez a tendo perdido, como se poderá saber se a recuperaria mais tarde?

— O vento desempenha essa função — disseram as areias. Eleva a água, a conduz sobre o deserto e depois a deixa cair. Caindo na forma de chuva, a água novamente se converte em rio. - Como posso saber se isto é verdade? - Pois assim é, e se não acredita, não se tornará outra coisa senão um pântano, e ainda isto levaria muitos e muitos anos; e um pântano não é certamente a mesma coisa que um rio. - Mas não posso continuar sendo o mesmo rio que sou agora? — Você não pode, em caso algum, permanecer assim — retrucou a voz. - Sua parte essencial é transportada e forma um rio 
novamente. Você é chamado assim ainda hoje por não saber qual a sua parte essencial.

Ao ouvir tais palavras, certos ecos começaram a ressoar nos pensamentos mais profundos do rio. Recordou vagamente um estágio em que ele, ou uma parte dele, não sabia qual, fora transportada nos braços do vento. Também se lembrou, ou the pareceu assim, de que era isso o que devia fazer, conquanto não fosse a coisa mais natural.

E o rio elevou então seus vapores nos acolhedores braços do vento, que suave e facilmente o conduziu para o alto e para bem longe, deixando-o cair suavemente tão logo tinham alcançado o topo de uma montanha, milhas e milhas mais distante. E porque tivera suas dúvidas, o rio pôde recordar e gravar com mais firmeza em sua mente os detalhes daquela sua experiência. E ponderou: — Sim, agora conheço minha verdadeira identidade.

O rio estava fazendo seu aprendizado, mas as areias sussurravam:

- Nós temos o conhecimento porque vemos essa operação ocorrer dia após dia, e porque nós, as areias, nos estendemos por todo o caminho que vai desde as margens do rio até a montanha.

E é por isso que se diz que o caminho pelo qual o Rio da Vida tem que seguir em sua travessia está escrito nas Areias. Idries Shah, Histórias dos dervixes. 


\section{Narrativas Imemoriais}

A lenda das areias circula na tradição oral de muitas línguas. A presente versão, recontada por Idries Shah, é baseada no texto de Awad Afifi, o Tunísio, que faleceu em 1870, e foi publicada no livro intitulado Histórias dos dervixes, contendo histórias decorrentes dos mestres e escolas sufis durante os últimos mil anos.

O material de ensino usado pelos sufis sempre tem sido encarado unicamente segundo o critério de aceitação deles próprios, afirma o autor no prefácio da obra e acrescenta, de acordo com a cultura local, a audiência e os requisitos do Ensinamento, que os sufis lançaram mão, tradicionalmente, de textos selecionados com critério na incomparável fonte de riqueza de sua sabedoria transmitida.

Nos círculos sufis é costume que os alunos assimilem profundamente as histórias programadas para seus estudos, a fim de que sua dimensão interior possa ser esclarecida pelos mesmos mestres à medida que o candidato se torne amadurecido para as experiências que as mesmas proporcionam.

Ao mesmo tempo, muitos contos sufis foram incorporados ao folclore ou a ensinamentos éticos, ou ainda se infiltraram em obras biográficas. Muitos deles proporcionam alimento espiritual em níveis variados, e seu valor como obras de puro entretenimento não pode ser negado. (Shah, 1976, p. 13)

Idries Shah - cujo nome completo é Nawab-Zada Sayed Idries Shah el Hashimi - é um dos grandes escritores da escola sufi. Autor de diversas obras, agora traduzidas em vários idiomas, sobre o tema do sufismo, milenar escola 
literária e filosófica que exerceu profunda influência em diversos autores ocidentais, como Robert Graves e Jorge Luis Borges, dentre outros. Doris Lessing, aclamada autora contemporânea de língua inglesa, natural do Oriente Médio, entre várias obras premiadas, publicou o livro Canopus in Argos: Archives (1979-1983) em 1996, dedicado ao tema do sufismo e, por ocasião do falecimento de seu mestre, Idries Shah, ela escreveu:

É um clichê dizer que um livro mudou a vida da gente, mas foi exatamente o que aconteceu comigo após a leitura de Os sufis, escrito por Idries Shah, em 1964. [...] Idries Shah era uma ponte entre as culturas; como seu pai, Sirdar Ikbal Ali Shah, ele se sentia em casa tanto no Ocidente quanto no Oriente. [...] Homem multifacetado, conhecedor dos assuntos mais variados, era a pessoa mais inteligente e gentil que conheci. (Lessing, 2005)

Grande responsável pela divulgação do pensamento sufi no Ocidente, Idries Shah teve sua obra-prima, Os sufis, prefaciada pelo inglês Robert Graves, autor de Lawrence da Arábia, considerado como um dos autores mais versáteis e originais do século XX. É ele quem melhor define a escola sufi:

Os sufis são uma antiga maçonaria espiritual cujas origens nunca foram traçadas nem datadas; nem eles mesmos se interessam muito por esse tipo de pesquisa, contentando-se em mostrar a coerência de sua maneira de pensar em diferentes regiões e períodos. (Graves, 1977, p. 7)

Também conhecida simplesmente como $A$ Tradição, a escola sufi, cujo veículo para transmissão de sabedoria, constitui justamente a narrativa, teria permeado toda a história literária sem jamais constar nos textos canônicos. Herdeiros do legado da tradição oral, os adeptos do sufismo teriam evitado explicitar sua ligação oculta, de modo que sua influência só poderia ser percebida pelos "iguais", permanecendo invisível aos olhos incautos do observador acadêmico. 
Graves (1977, p. 7) afirma:

Não obstante, segundo Ali el-Hujwiri, escritor sufista primitivo e autorizado, o próprio profeta Maomé disse: "Aquele que ouve a voz do povo sufista e não diz aamin (amém) é lembrado na presença de Deus como um dos insensatos". Numerosas outras tradições o associam aos sufis, e foi em estilo sufista que ele ordenou a seus seguidores que respeitassem todos os Povos do Livro. [...]

Os estudiosos ocidentais parecem não ter se dado conta de que até o conteúdo do popular As mil e uma noites é sufista e o título é sufista e que o seu título árabe, Alf layla uwa layla, é uma frase codificada que lhe indica o conteúdo e a intenção principal: Mãe de lembranças.

Talvez possamos equiparar o significado oculto das Mil e uma noites ao poder da evocação das lembranças, das memórias, ou seja, as terras férteis da mãe de todas as musas: Mnemósine. Graves (1977, p. 10) acrescenta que "os sufis insistiram sempre na praticabilidade do seu ponto de vista. A metafísica, para eles, é inútil sem as ilustrações práticas do comportamento humano prudente, fornecidas pelas lendas e fábulas populares".

A narrativa popular, teria sido, justamente, o grande veículo de transmissão dessa sabedoria. Não por acaso, pode-se perceber suas reverberações em histórias até hoje mundialmente conhecidas, como a lenda de Guilherme Tell. Afirma Graves (1977, p. 11):

Abundam exemplos, em toda literatura européia, da dívida para com os sufis. A lenda de Guilherme Tell já se encontrava em A conferência dos pássaros, de Attar (século XII), muito antes do seu aparecimento na Suíça; e a lenda de que os grupos germânicos de arqueiros (se pudermos confiar no Malleus maleficarum, manual de caça às bruxas de 1460) atiravam "em nome do diabo", em maçãs colocadas de maneira semelhante, sugere 
influência sarracena. E, embora Dom Quixote pareça o mais espanhol de todos os espanhóis, o próprio Cervantes reconhece sua dívida para com uma fonte árabe.

Esta imputação foi posta de lado, como quixotesca, por eruditos; mas as histórias de Cervantes seguem, não raro, as de Sidi Kishar, lendário mestre sufista às vezes equiparado a Nasrudin, incluindo o famoso incidente dos moinhos (aliás de água, e não de vento) tomados equivocadamente por gigantes. A palavra espanhola Quijada (verdadeiro nome do Quixote, de acordo com Cervantes) deriva da mesma raiz árabe KHSR de Kishar, e conserva o sentido de "caretas ameaçadoras".

Se retomarmos como verdadeira a premissa de Lotman no sentido de que a cultura funcionaria como uma inteligência coletiva e uma memória coletiva, e que o espaço da cultura pode ser definido como um espaço de certa memória comum, um lugar no qual alguns textos comuns conseguem conservar-se e ser atualizados, podemos levantar a hipótese de que a arte da narrativa sufi constituía-se como um esforço no sentido de criar textos constantes, cuja capacidade multiplicadora de significados seja forte o suficiente a ponto de garantir sua sobrevivência através de diferentes tempos e lugares. Daí, justamente, a importância da bela metáfora da lenda das areias, pois apenas os textos narrativos capazes de serem absorvidos e transportados pelos "ventos" teriam a capacidade alquímica de transmutar-se no ouro da sabedoria universal.

Talvez seja justamente essa lenda que Borges homenageia ao criar sua bela obra O livro da areias, na qual seu personagem, Alejandro Ferri, afirma: "As palavras são símbolos que postulam uma memória compartilhada". (Borges, 2004, p. 34)

Para Cecilia Almeida Salles (2006, p. 102), todo processo de criação seria, antes de mais nada, "um percurso tradutório e, portanto, organicamente intersemiótico. Sendo, portanto, de extrema importância, uma abordagem que compreenda a criação em sua rede complexa de interações em permanente mobilidade". A metáfora da rede em movimento, abrangendo todos os objetos de 
interesse do criador, seja um romance, uma peça publicitária, uma escultura ou um artigo científico, ou ainda jornalístico, constituiriam uma possível versão daquilo que pode vir a ser ainda modificado.

Ora, o movimento, a impermanência e o consentir em ser transmutado são exatamente aquilo que o vento exige do rio para que ele alcance a vida eterna.

No conto "O Outro", que abre O livro das areias, Jorge Luis Borges, tornado personagem, sonha consigo mesmo, e, numa referência explícita ao sonho da borboleta, um sonhador confunde-se com o outro dentro de um flutuante e fértil espaço onírico. Para atestar sua realidade, o narrador diz a seu duplo:

- Posso te provar que não minto. Vou te dizer coisas que não pode saber um desconhecido. Em casa há uma cuia de prata com um pé de serpentes, que trouxe do Peru nosso bisavô. Há também uma bacia de prata, que pendia do arção. No armário de teu quarto há duas fileiras de livros. Os três volumes de Mil e Uma Noites de Lane, com gravuras em aço e notas em corpo menor entre os capítulos, o dicionário latino de Quicherat, a Germânia de Tácito em latim e na versão de Gordon, um Dom Quixote da editora Garnier, as Tablas de Sangue de Rivera Indarte, com a dedicatória do autor, o Sartor Resartus de Carlyle, uma biografia de Amiel e, escondido atrás dos demais, um livro em brochura sobre os costumes sexuais dos povos balcânicos. (Borges, 2004, p. 10)

Quando o duplo do narrador lhe confessa segredos que não se diz a um desconhecido, desvenda, metaforicamente, uma dimensão da literatura e suas redes subliminares normalmente ignoradas pela história da literatura oficial.

Se pensarmos na técnica narrativa cinematográfica, nitidamente inspirada no folhetim, criado por Alexandre Dumas, que por sua vez, utilizou os recursos da personagem de Sherazade, das Mil e uma noites, perceberemos que, de fato, a dívida da cultura ocidental, com relação à obra-prima da literatura árabe, é imensa. 
Contudo, raramente se percebem os fios de conexão que atravessam os tempos e lugares. Idries Shah, autor oriental, tenta percorrer a obra de autores como Hans Christian Andersen, dentre outros, ressaltando os pontos de convergência entre alguns de seus contos e as histórias árabes de ensinamentos.

Um método sufista tradicional para referir-se a esta situação é empregar uma analogia. Os sufis, também tradicionalmente, empregam analogias familiares às pessoas às quais se dirigem. Os leitores ocidentais deste livro hão de conhecer, por força, a história de Hans Christian Andersen intitulada o "O Patinho Feio". O patinho achava-se feio; e de fato o era, do ponto de vista dos patos. Mas tudo acabou bem porque se descobriu que ele era um cisne. O germe dessa história encontra-se em Mathanwawi, de Jalaluddin Rumi, onde se dá realce a um ponto que se perdeu na versão dinamarquesa porque visava um público diferente. Rumi chama seus ouvintes de "patos que estão sendo criados por galinhas". Cumpre-Ihes compreender que o seu destino é nadar e não tentar ser frangos. (Shah, 1977, p. 358)

Todavia, nem sempre a história da literatura ocidental preocupa-se em estabelecer esses vínculos, percorrer as bibliotecas dos autores e o diálogo que estabelecem com outras tradições, mesmo que expressos em suas obras e depoimentos, como fizeram Alexandre Dumas e Marcel Proust, ambos leitores confessos das histórias de Sherazade. Ao evitar esse caminho, deixa-se de perceber a riqueza criativa que nasce no ato de ressignificar um texto de modo a reinseri-lo na memória cultural.

Se a antologia árabe Mil e uma noites constitui-se como uma obra que talvez possa ser considerada como um texto constante, segundo definição de Lotman, devemos considerar o caráter móvel dessas mesmas narrativas. Finais em aberto, histórias que se encaixam umas nas outras, de origem e autoria controversas, As mil e uma noites são constantemente transformadas como as águas do lendário rio citado no início deste capítulo, atuando, portanto, também como um texto móvel, segundo a definição de Philippe Willemart (2005, p. 14): 
O texto móvel — na medida em que passa pela representação do manuscrito ou entrando no registro do imaginário, adquire um sentido destrói-se, sofre um desvanecimento (Lacan) - como o sujeito do inconsciente - e volta à sua forma informe, imersa no grão do gozo que determina sua estabilidade.

O conceito da mobilidade dos textos e sua capacidade constante de gerar outros textos vão ao encontro das palavras de Lotman (1996, p. 152), que definem a memória cultural

\begin{abstract}
como mecanismo criador que não apenas deixa de ser pancrônica, mas também se opõe ao tempo. [...] Por isso, o estudo da literatura em termos de história, na forma como se acreditou primeiramente em termos de teoria hegeliana da cultura, e depois a teoria positivista do progresso, é realmente anti-histórico, pois omite o papel ativo da memória na geração de novos textos. ${ }^{8}$
\end{abstract}

Consideramos a metáfora oriental da literatura, como sendo um mar de histórias, tão adequada quanto o belo pacto que o rio estabelece com o vento para garantir a própria sobrevivência. Espaços orgânicos em constante movimento, textos móveis, mas como que multiplicados em sutis fios constantes, capazes de banhar diferentes tempos, espaços e povos.

A memória e sua relação com a comunidade também surgiram como objeto de estudo de Paul Zumthor, cuja obra $A$ letra e a voz explorou a complexidade da relação entre o Ocidente Medieval e algumas práticas poéticas do

8 "La memoria cultural como mecanismo creador no solo es pancrónica sino que se opone al tiempo. Conserva lo pretérito como algo que está. Desde el punto de vista de la memoria como mecanismo que trabaja con todo su grueso, el pretérito no ha pasado. Por eso, en el estudio de la literatura el historismo, en la forma en que lo creo primeramente la teoría hegeliana de la cultura, y después la teoría positivista del progreso, es realmente antihistórico, ya que hace caso omiso del papel activo de la memoria en la generación de nuevos textos." 
Extremo Oriente. Além de abordar a questão da "movência", ou seja, da natureza orgânica da poesia e sua criação, ele ressaltou a função estabilizante da voz poética dentro de um grupo social.

A voz poética assume a função coesiva e estabilizante sem a qual o grupo social não poderia sobreviver. Paradoxo: graças ao vagar de seus intérpretes - no espaço, no tempo, na consciência de si - a voz poética está presente em toda a parte, conhecida de cada um, integrada nos discursos comuns, e é para eles referência permanente e segura. Ela thes confere figuradamente alguma extratemporalidade: através dela, permanecem e se justificam. Oferece-lhes o espelho mágico do qual a imagem não se apaga, mesmo que eles tenham passado. As vozes cotidianas dispersam as palavras no leito do tempo, ali esmigalham o real; a voz poética os reúne no instante único - o da performance - tão cedo desvanecido que se cala; ao menos, produz-se essa maravilha de uma presença fugidia, mas total. [...] A memória, por sua vez, é dupla: coletivamente, fonte de saber; para o indivíduo, aptidão de esgotá-la e enriquecê-la. Dessas duas maneiras, a voz poética é memória. [...] A ficção é um estado de linguagem, esse modo flutuante de existência. (Zumthor, 1993, p. 159)

Pois bem, a capacidade de transmitir a fragilidade da condição humana, a incapacidade de apreensão da realidade como um todo e o estado orgânico em transmutação eterna são conceitos constantes nas fábulas sufis; porém, no lugar de ressaltar esses elementos como sendo geradores de eventos trágicos, muitas vezes as histórias milenares de personagens como Sherazade ou Nasrudin optam pelo humor e surpresa. Afinal, estamos todos no mesmo barco, mesmo que ele esteja à deriva, furado, naufragando. O próprio termo barco deriva da palavra árabe baraka (Shah, 1977, pp. 14; 30), que pode ser traduzida por bênção sutil ou bemaventurança impalpável, um conceito de extrema importância para essa literatura.

Idries Shah ressalta, em seus estudos, os vínculos entre a obra de Rumi, o grande fabulista da Ásia Menor, e Esopo, comparando versões diferentes de 
fábulas narradas por ambos. Rumi viveu dois mil anos antes de Esopo e teria afirmado que uma fábula, fictícia ou não, ilumina a verdade.

Operando por meio de analogias, parábolas, essa família de contadores de histórias não tinha como intenção ensinar ou pregar, mas, sim, despertar certa atenção da parte do ouvinte ou leitor, desalojando-o de suas crenças e certezas, de modo a fazê-lo renascer para novas possibilidades e novos deslocamentos da sensibilidade.

Ao longo da bela análise que empreende das Mil e uma noites, Barcia Gomes (2000, p. 144) pergunta-se:

Será essa uma narrativa desesperançada? Talvez seja uma narrativa de compaixão - da compaixão de Scheerazade pelo louco marido. Ambos, Shariyar e Scheerazade, estão irmanados na fragilidade frente ao destino, tanto o pulsional quanto o institucional, e têm pouco a fazer. Talvez só Ihes reste a saída que tomou o califa Haroun al-Raschid; ele não abandonou o reino, por sentir-se indigno, nem recorreu a vinganças terríveis, apenas permaneceu íntegro, uno, em sua dor, que não procurou esconder, e em seu amor, que proclamou por toda Bagdá.

Essa talvez tenha sido a lição mais contundente sobre a condição humana que Scheerazade tenha podido apresentar ao sultão.

Segundo Idries Shah, a literatura mundial sobre sufismo é ampla, há várias traduções das fábulas e ensaios. No entanto, os escritos sufistas não seriam apenas material literário, filosófico ou técnico. A apresentação do sufismo ao homem culto, numa língua ocidental, revela uma condição de literatura que não talvez não encontre similar em nenhum outro campo. Trata-se de um processo caleidoscópico, ele afirma, marcado por um elemento de policotomia, termo que opõe à dicotomia, traduzindo sempre o conceito da multiplicidade de facetas da percepção.

Justamente, uma das mais famosas fábulas sufis descreve uma situação na qual sete sábios apalpam um mesmo elefante, tentando descrevê-lo da melhor 
forma possível. Como cada cego toca uma parte do corpo do animal, jamais chegam a um consenso. "Assim os homens se portam diante da verdade, pegam apenas uma parte, ignoram o todo e continuam sempre tolos", declara o mais sábio dos cegos no final (Shah, 1976, p. 27).

Sutilezas e múltiplos significados, além de humor, caracterizam grande parte dessas narrativas, afirmava o poeta Rumi: "coisas opostas trabalham juntas, ainda que se oponham nominalmente" (Shah, 1977, pp. 72-3).

Que idade tem, exatamente, a palavra "sufismo"? Houve sufis em todos os tempos e em todos os países, consoante a tradição. Os sufis existiam como tais e sob esse nome antes do islamismo. Entretanto, se havia um nome para o praticante, não o havia para a prática. A palavra "sufismo" deriva de sufismos latino; foi um erudito teutônico que, já em 1821, cunhou a latinização que está agora quase naturalizada em todas as línguas ocidentais. Antes dela existia a palavra tsawwwuf - o estado, a prática ou a condição de ser sufi. Isso pode não parecer um ponto importante para nós, mas o é para os sufis. Razão pela qual não há um termo estático em uso entre eles que Ihes designe o culto. Chamam-Ihe ciência, arte, conhecimento, caminho.

O monge na cela, o faquir no topo da montanha, o mercador na loja, o rei no trono - todos podem ser sufis, mas isso não é o sufismo. Quer a tradição sufista que o sufismo seja um fermento dentro da sociedade dos homens. A própria diversidade não the permite ser sistematizado na forma semipermanente que o deixaria tão estático que pudesse ser investigado. "O sufismo", no dizer do sufi, "é uma aventura da vida, uma aventura necessária" (Shah, 1977, pp. 7-12).

"Faz-se o iogurte adicionando pequena quantidade de iogurte velho a uma quantidade maior de leite. A ação do Bacillus bulgaricus sobre a porção germinal de iogurte converterá o todo, com o tempo, numa massa de iogurte novo." (Shah, 1977, p. 76)

É exatamente à metáfora do fermento que Cecilia Almeida Salles se refere para definir o processo de criação em rede: 
Tomemos a imagem de proteínas interagindo no fermento que talvez nos auxilie a visualizar essa ação de um elemento sobre o outro, que queremos enfatizar. É interessante observar a conseqüência dessa interação sob a forma de ramificação de novas possibilidades — uma ação geradora.

O pensamento em criação manifesta-se, em muitos momentos, por meios bastante semelhantes a esse que aqui vemos. Uma conversa com um amigo, uma leitura, um objeto encontrado ou até mesmo um novo olhar para a obra em construção pode gerar essa mesma reação: várias novas possibilidades que podem ser levadas adiante ou não. As interações são muitas vezes responsáveis pela proliferação de novos caminhos. (Almeida Salles, 2006, p. 25)

Diríamos que multiplicidade, acasos, surpresas ou policotomias, ou seja, a arte sufi de abordar o tema de vários ângulos - e logo se afastar, deixando ao leitor a tarefa de conduzir o próprio processo de compreensão - , que conduzem à criação, é plena de sutilezas, nuanças essas que certamente mereceriam um destaque maior nos estudos voltados à história da literatura, infelizmente muitas vezes ainda marcado pela cronologia, ou por rígidas concepções de escolas literárias, bem como por dicotomias redutoras como as que atrelam a obra apenas à biografia.

Deixar-se conduzir no ritmo e da movência da própria linguagem, nas redes de criação que surgem a partir da escolha de um determinado gênero literário como suporte da narrativa, nas leis individuais e intransferíveis de cada obra, pressupõe uma abertura de espírito condizente apenas com um abandono de noções pré-concebidas, ou, como diria o poeta sufi Saadi, em sua obra, Jardim das rosas (apud Shah, 1977, p. 218):

No fundo do mar há riquezas incomparáveis.

Mas se queres segurança, busca-a na praia. 
Capítulo 7

Os Caminhos da Memória 
Temos todos duas vidas:

a verdadeira, que é a que sonhamos na infância, e a que continuamos sonhando, adultos, num substrato de névoa.

Fernando Pessoa, Quando fui outro. 


\section{Os Caminhos da Memória}

Afirma o poeta português:

Toda literatura consiste num esforço para tornar a vida real. Como todos sabem, ainda quando agem sem saber, a vida é absolutamente irreal, na sua realidade direta; os campos, as cidades, as idéias, são coisas absolutamente fictícias, filhas da nossa complexa sensação de nós mesmos. São intransmissíveis todas as impressões salvo se as tornarmos literárias. As crianças são muito literárias porque dizem como sentem e não como deve sentir quem sente segundo outra pessoa. Uma criança, que uma vez ouvi, disse, querendo dizer que estava à beira de chorar, não "Tenho vontade de chorar", que é como diria um adulto, isto é, um estúpido, senão isto: "Tenho vontade de lágrimas". E esta frase, absolutamente literária, a ponto de que seria afetada num poeta célebre, se ela pudesse dizer, refere resolutamente a presença quente de lágrimas a romper das pálpebras conscientes de amargura líquida. "Tenho vontade de lágrimas"! Aquela criança pequena definiu bem a sua espiral. (Pessoa, 2006, p. 28)

Sempre que conversa com seus jovens leitores, a escritora Tatiana Belinky, um dos maiores nomes no cenário nacional, diz que "não existe melhor mágica do que abrir um livro e tirar dele uma história"9.

O encantamento com as primeiras leituras aliado à perspicácia da infância, tão bem descritos pela pena de Fernando Pessoa, fazem do leitor infantil uma criatura privilegiada.

Quando um escritor se propõe a resgatar a apreensão do mundo enquanto visto pela criança e assim rejuvenescer a sensibilidade adulta, recordando-

\footnotetext{
${ }^{9}$ Em entrevistas informais durante o ano de 2006.
} 
o do estado de permeabilidade inerente aos primeiros anos, temos uma obra-prima como Em busca do tempo perdido, de Marcel Proust.

"Um narrador nos conta que ao voltar para casa em certa tarde de inverno, tremendo de frio, aceita, a contragosto, uma xícara de chá com um bolinho seco. Mal sente o gosto do chá misturado com a massa do bolo, a famosa Madeleine, ele é tomado por uma memória involuntária, tendo acesso a todo um passado de riquezas esquecidas".

"Nesse tempo que já se foi, a vida desse narrador girava em torno de uma cidadezinha fictícia, chamada Combray, onde costumava passar as férias. Para chegar até ela, havia dois caminhos possíveis: o mais curto, atravessando a propriedade de um homem muito fino, chamado Swann, e o longo caminho de Guermantes, trilha fluvial".

Destaca Guilherme Ignácio da Silva, em seu prefácio à obra traduzida pelo poeta Mário Quintana, que, na verdade, esse itinerário designa outros caminhos da memória:

Já o outro significado desse título envolve a própria história da criança que vem com os pais em visita à cidade de Combray e que, muito mais tarde, vai se tornar o narrador do livro que estamos lendo. Para ele, percorrer o caminho de Swann é percorrer o mesmo trajeto da personagem Swann, experimentar as mesmas dores no amor, o ciúme, o contato com a arte e compreender como Swann pôde lidar com tudo isso. Em Busca do Tempo Perdido começa assim, como no início de uma caminhada, de uma longa caminhada de leitura no sentido da vida. [...] Não seria esse um sonho comum a todos nós? Sonho de, no momento de maior fragilidade e desesperança de nossa existência, no instante em que o tênue fio que nos prende à vida está prestes a romper-se ou, quando não, já não há algum tempo se esvaiu, sem que notássemos e, de repente, pudéssemos recuperar, sem qualquer esforço, uma vibração que nada mais é do que o sentido profundo de tudo que até então vivemos? (Ignácio da Silva, 2006, p. 8) 
Segundo preceitos da tradição sufi, conforme expressos na obra de Baha Walad, mestre árabe do século XII, pai de Rumi, o grande poeta dessa tradição, durante o período da infância o ser humano permanece próximo ao território divino. Adulto, ele sofre, porque a vida o afastou da percepção divina da vida. O humor e a risada infantil seriam expressões da tolerância e da compreensão inatas que são destruídas pelas ilusões do véu, a falsa vida que a idade adulta tanto preza ${ }^{10}$. (Chittick, 2000, p. 103)

Ora, a literatura tradicionalmente destinada à infância é chamada de contos de fadas. Marina Warner (1999), estudiosa do gênero, destaca a origem da palavra fada, cujo significado remonta ao termo fata, variante rara de fatum, a deusa do destino. Conhecedoras dos caminhos da sorte, as fadas compartilham com as míticas Sibilas o conhecimento do futuro e do passado.

Isidoro de Sevilha (m.636), em Etymologies, propõe a famosa e cética definição da idéia pagã do fado e das Parcas: "Dizem que o fado é aquilo que os deuses declaram, aquilo que Júpiter declara. Sendo assim, dizem que o fado deriva de fando, ou seja da fala [...]. Segundo a ficção existem três Parcas, que tecem com os dedos um fio de lã numa roca de fiar ou num fuso, refletindo a natureza tripla do tempo; o passado, que já está tecido e enrolado no fuso; o presente, que está passando pelos dedos da fiandeira, e o futuro, que repousa na lã enrolada na roca e que precisa ser puxado pelos dedos da fiandeira até o fuso, enquanto o presente converte-se em passado". Essas Parcas clássicas se metamorfosearam nas fadas das histórias, onde continuaram a ter um papel profético e fatal. Mas os próprios contos de fadas também cumprem essa função, a despeito das fadas, que podem ou não aparecer: contos como "Barba Azul" ou "A Bela e a Fera" alertam os ouvintes ao mesmo tempo que iluminam seu caminho para o futuro. (Warner, 1999, p. 41)

10 "Wherever there is weeping and laughing, the laughter is because of union with God's bounties. When a human child grows up from littleness, he is happy in God's bounties. In old age, he is sad and weeping because of the separation from God's bounties. He laughs in Him and weeps in separation from Him." 
Situando sua narrativa nesse misterioso tempo que se situa entre o sono e a vigília, conforme afirma Jeanne-Marie Gagnebin, no posfácio ao volume 1, "No caminho de Swann", da obra Em busca do tempo perdido, Proust como que desafia a maestria das parcas e reinstaura a intensa percepção da infância, da capacidade literária inata das crianças, conforme a visão de Pessoa, a proximidade com a sabedoria divina, de acordo com os preceitos sufis.

Ao suprimir o "eu", na medida em que não acrescenta dados biográficos precisos, como data de nascimento ou sobrenome a Marcel, nome de menino pronunciado apenas uma ou duas vezes ao longo de milhares de páginas, ao indeterminar tempo e espaço de narrativa, extirpando também referências espaciais precisas, ao eleger a trivialidade como foco propulsor de memórias aparentemente aleatórias, Proust tece um tempo mágico, no qual tudo pode acontecer, em desobediência às convenções, sejam elas de ordem social ou literária.

Paradoxalmente, essa inconsistência voluntária e tão habilmente criada desperta certo temor, uma necessidade de controle, certo suspense. Como a criança que não tem consciência de sua finitude, indefinitude, à medida que ainda não sabe o que virá a ser, de sua dependência de adultos, nós, leitores, nos encontramos à mercê desse narrador para descobrir o que serão esses personagens que ele nos apresenta, como transformarão o narrador e a nós mesmos, em simbiose profunda com esse Marcel sem "lenço nem documento".

No universo proustiano, toda a parafernália que a sociedade burguesa criou para exercer controle aparente sobre o acaso se desmancha, de modo que, semelhante a uma narrativa de contos de fadas, cada mulher pode ocultar uma feiticeira e Barba Azul se esconde atrás de cada porta fechada.

Caminhando pelos luxuosos corredores habitados por seus personagens, sente-se tanta desorientação como os primeiros a adentrar nas cavernas imemoriais das temíveis Sibilas, videntes e contadoras de histórias, conforme o texto de Marina Warner (1999, p. 27): 
Quando parecia que o cristianismo estava tomando conta de sua Campânia natal, no sul da Itália, a Sibila deixou seu labirinto de cavernas em cumas, sob o templo de Apolo. Lá proferira seus oráculos durante séculos, mas partia rumo às montanhas para criar um dos últimos postos do paganismo, no mais alto cume dos montes Apeninos, ainda chamados de monti Sibillini em sua homenagem.

Ela mostrara a Enéias o caminho para o mundo subterrâneo pagão na épica de Virgílio; vendera os volumes de tábuas sibilinas, seus oráculos em formas de salmos, ao último rei de Roma, Tarquínio, o Soberbo, provando que tinha sabedoria mundana e astúcia; quando este se recusou a pagar seu preço pelos nove livros, ela queimou três dele; como ainda assim ele se recusasse a pagar, queimou mais três. Diante desse xeque-mate, o rei foi obrigado a pagar o preço integral pelos três volumes restantes, para não correr o risco de que fossem totalmente destruídos. Mas, com a nova fé ganhando terreno, a autora dos oráculos foi obrigada a fugir e a se esconder numa gruta onde pudesse praticar em segredo suas artes proibidas. Uma dessas artes era inventar histórias, passar informações, transmitir aos seus ouvintes uma imagem do que o futuro poderia reservar.

Pois bem, no Capítulo 6 destaquei a metáfora sufi do fermento como símbolo daquilo que é novo e que brota naturalmente ao mesclar-se com o que era antigo. Mencionei também a rede geradora de narrativas e sua movência, a capacidade de deslocar-se e adaptar-se a novos tempos e lugares. Dentro dessa ótica, a memória e a tradição atuariam como terrenos de fecundidade criativa, inseridos numa dinâmica de constante transformação. Retomarei ainda a concepção de memória segundo o escritor Jorge Luis Borges e o semioticista luri Lotman.

Para Borges, a originalidade e a autoria absolutas seriam ilusões, cabendo à memória a função de fonte geradora de novas obras, memória essa que ele concebe como um manancial de novas combinatórias poéticas, uma memória situada na zona fronteiriça entre sono e vigília, uma memória "superior ao pensamento". Para Lotman (1996), "a cultura seria uma inteligência coletiva e uma memória coletiva, isto é, um mecanismo supra-individual de conservação e 
transmissão de certos comunicados (textos) e da elaboração de novos". Dentro desse enfoque, o cultivo e a própria tentativa de preservação da memória implicam a necessidade da escolha daquilo que deve ser narrado às futuras gerações.

Lembremos também as palavras de Jerusa Pires Ferreira quando ressalta o fato de que, para Lotman, a Cultura, em essência, se dirige contra o esquecimento. De forma que, para tentar compreender a memória cultural é preciso examinar tudo que a bloqueia, nega ou anula.

Talvez seja justamente nesse sentido que o futuro, desvendado nos oráculos de Sibila, citado anteriormente, surja como elemento profano, capaz de libertar a criação literária do controle canônico, a uma determinação de escolha social dirigida. Autores malditos de sucesso póstumo, como os poetas Charles Baudelaire e Gerard de Nerval, produziram obras profanas de intensa influência nos escritores que os procederam, obras essas em que prevalecem o sonho, a loucura, as zonas fronteiriças impossíveis de serem contidas pelo jugo das convenções sociais.

Nesse sentido, aproximando-nos da visão de Borges, poderíamos sugerir que a autoria, o controle e a escolha são momentâneos, para não dizer ilusórios, já que nem sempre os autores aclamados por um determinado grupo, em determinada época, têm obras longevas, ao passo que o contrário, obras mal compreendidas por editores, como teria acontecido com Proust, por exemplo, deslocam-se para a condição de textos constantes, sem que seja possível barrá-las.

A memória cultural apresentaria, portanto, uma dinâmica autônoma, orgânica, refratária a classificações e/ou mecanismos de contenção.

Marina Warner (1999, p. 35) prossegue em seu estudo sobre o mito da Sibila, destacando o paradoxo que sua figura contém:

Ela é exilada, até abandonada; sua voz é abafada, até emudecida. Contudo, presa às grilhetas do monumento, ela continua a falar: 
"E por minha voz serei conhecida": nada mau como epitáfio para um narrador de histórias.

Como no caso de tantos outros mitos gregos, e aqui podemos citar o sofrimento de Sísifo, condenado a empurrar pedras montanha acima, ou Ícaro, morto em seu vôo rumo ao Sol, a busca da sabedoria é não só profana quanto inglória e penosa. Warner acrescenta sua interpretação da Sibila, afirmando que sua

caverna representa um palácio do prazer, um sonho de alegria e delícias inesgotáveis - criação de uma figura que ao mesmo tempo é narradora de histórias (Sibila, a profetisa) e protagonista das lendas múltiplas que inspira. $O$ valor negativo atribuído ao seu reino nunca chega a convencer totalmente; continua sendo ao mesmo tempo um jardim de deleites mundanos, um paraíso de fato, do qual seus visitantes, seus relatores, são servos. [...] A Sibila, enquanto figura de narradora de histórias, faz a ponte entre segmentos da história bem como entre hierarquias de classe. Oferece a sugestão de que afinidades podem trafegar entre países e línguas, bem como entre pessoas de diferentes status. Ela também representa uma sobrevivente cultural imaginária na passagem de uma era de crenças para outra. A Sibila existe como uma fantasia cristã sobre uma presença pagã no passado e como tal cumpre uma certa função no pensamento sobre questões proibidas, esquecidas, enterradas e até secretas. (Warner, 1999, p. 36)

Se levarmos em consideração a dinâmica dos textos excluídos segundo o pensamento de Lotman, podemos aventar a hipótese de que, talvez, justamente essas narrativas malditas sejam, ironicamente, aquelas que contêm maior capacidade de sobreviver. Warner afirma que, em determinado momento, na Inglaterra, os contos de fadas orais foram fixados em publicações para divertimento do público. De modo semelhante, na França, no fim do século XVII, quando o conto de fadas surgiu pela primeira vez em publicações, os comentadores os relacionaram 
às velhas senhoras. Além de divertir, eram utilizados como instrumento moralizador e socializador na vida das crianças.

As várias camadas de significados que impregnam os mitos e lendas, porém, podem despertar a atenção para o lado mais inquietante da existência. Mesmo que a narração aponte para uma moral, geralmente externa à estrutura do conto em si, a narrativa arcaica, arquetípica, é, como diriam os sufis, policotômica, projetando significados por vezes totalmente antagônicos à moral vigente. Portanto, um mito como o da Sibila desafia a divisão de classes, desloca-se por diferentes regiões e sobrevive à passagem do tempo.

Aliás, Warner (1999, p. 20) menciona a querela quanto às origens dos mitos e das lendas. Afirma que

o difusionismo sustenta que as histórias são propagadas através de fronteiras, vindas de origens distantes - muitas vezes do Oriente. [...] Elementos do romance grego, dos moralistas romanos, das Mil e uma Noites, das fábulas com animais, dos chistes medievais e das vidas dos santos embaralham-se e unem-se com a descontraída ausência de inibição dos contos de fadas. A natureza do gênero é promíscua e onívora, bem como anarquicamente heterogênea, absorvendo elementos elevados e inferiores, tons trágicos e cômicos em sua estrutura narrativa freqüentemente simples e semelhante ao rondó. Os motivos e enredos são nômades, percorrendo o mundo e o milênio, surgindo em pergaminhos na Pérsia Medieval, em forma oral nos Pirineus, numa balada entoada nas regiões montanhosas, num conto de fadas do Caribe.

Uma teoria oposta - a dos arquétipos - propõe que a estrutura da imaginação e as experiências da sociedade humana inspiram soluções narrativas que se assemelham umas às outras, mesmo quando não teria sido possível haver nenhum contato ou troca; existem fábulas sobre metamorfoses de animais nas lendas algonquins e outros povos americanos nativos que parecem ecoar transformações ocorridas em contos de fadas asiáticos e europeus - ou vice-versa. Mas essas comparações costumam ser vagas; no que diz respeito a detalhes das narrativas e determinadas características do 
enredo (fibras de linho que fazem uma princesa cair em sono encantado; criados invisíveis e pratos que aparecem por vontade própria num castelo encantado), uma fonte literária em geral se encontra na origem da história.

É interessante reparar que Warner utiliza a expressão fonte literária para colocar-se, nitidamente, a favor da teoria do difusionismo. Há também, no segundo parágrafo citado acima, a expressão comparações vagas, quando a autora faz alusão à teoria dos arquétipos, cujo autor, o psiquiatra Carl G. Jung, nem sequer é citado. Digamos que, embora autora de um estudo fundamental, uma referência pontual para os pesquisadores de contos de fadas, é ela própria que, infelizmente, aborda a teoria dos arquétipos de modo vago e superficial. Pois, se, conforme afirma, as lendas e os mitos seriam soluções narrativas compondo a estrutura da imaginação, os mitos abordados pela teoria dos arquétipos independem da literatura escrita e a antecedem, de modo que realmente não se ocupam da questão da fonte literária ou origem, no sentido positivista e reducionista do termo.

Vejamos como é feita essa definição segundo o próprio Carl G. Jung (1988, p. 16):

O termo archetypus já se encontra em FILO JUDEU [...] como referência à imago dei no homem. Em IRINEU [...] também, onde se lê: "Mundi fabricator non a semetipso fecit haec, sed de alienis archetypis transtulit" (o criador do mundo não fez essas coisas diretamente a partir de si mesmo, mas copiou-as de outros arquétipos). No Corpus Hermeticum [...] Deus é denominado a luz arquetípica. Em DIONÍSIO AEROPAGITA encontramos esse termo diversas vezes como "De coelesti hierarchia" (os arquétipos imateriais) bem como "De divinus nominibus". O termo arquétipo não é usado em AGOSTINHO, mas sua idéia, no entanto, está presente; por exemplo em "De diversis quaestiobonus", "ideae... quae ipsae formatae non sunt... quae in divina intelligentia continentur" [...] (idéias... que não são formadas, mas estão contidas na inteligência divina". [...] Para aquilo que nos ocupa, a denominação é precisa e de grande ajuda, pois nos diz que, no 
concernente aos conteúdos do consciente coletivo, estamos tratando de tipos arcaicos ou melhor - primordiais - isto é, de imagens universais que existiram desde os tempos mais remotos. [...]

Outra forma bem conhecida dos arquétipos é encontrada no mito e no conto de fada. Aqui também, no entanto, se trata de formas cunhadas de um modo específico e transmitidas através de longos períodos de tempo. O conceito de "archetypus" só se aplica indiretamente às représentations colletives, na medida em que designar apenas aqueles conteúdos psíquicos que ainda não foram submetidos a qualquer elaboração consciente. Especialmente em níveis mais altos dos ensinamentos secretos, os arquétipos aparecem sob uma forma que revela seguramente a influência da elaboração consciente, a qual julga e avalia. Sua manifestação imediata, como a encontraremos em sonhos e visões, é muito mais individual, incompreensível e ingênua do que nos mitos, por exemplo. $O$ arquétipo representa essencialmente um conteúdo inconsciente, o qual se modifica através de sua conscientização e percepção, assumindo matizes que variam de acordo com a consciência individual na qual se manifesta. [...]

O conceito de arquétipo, que constitui um correlato indispensável da idéia do inconsciente coletivo, indica a existência de determinadas formas na psique, que estão presentes em todo o tempo e lugar. A pesquisa mitológica denomina-as "motivos" ou "temas"; [...] Adolf Bastian designou-as bem antes como "pensamentos elementares" ou "primordiais".

A definição acima, portanto, não induz a reduções simplistas no sentido de procurar, na literatura, imagens semelhantes para classificá-las estreitamente segundo um cânone redutor interpretador de arquétipos. Pelo contrário, quando se refere ao arquétipo da anima, por exemplo, Jung a exemplifica por meio do mito oriental da maia, a dançarina geradora de ilusões, considerando como anima as figuras femininas que encobrem, enlaçam e absorvem, sugando e tragando a figura masculina de tal modo que o mundo real se lhe retraia.

Conforme já mencionamos ao longo deste estudo, mitos atuam pela policotomia, ou seja, pela multiplicidade de significados; isso quer dizer que Jung 
referiu-se a eles justamente para impregnar de muitas nuanças e possibilidades sua interpretação. Reduzir o mito a um molde afirmando tratar-se de um arquétipo contraria a própria natureza do pensamento junguiano que não se caracteriza por um viés limitador ou tampouco simplificador.

Em sua obra O tao e a psicologia, toda ela repleta de ricas referências à literatura chinesa, o psiquiatra Paulo Vicente Bloise (2000, p. 156) nos oferece o seguinte comentário a respeito da definição junguiana de arquétipo:

Para Jung, todo indivíduo teria em seu inconsciente algo mais que as recordações e materiais reprimidos da experiência pessoal: haveria ainda as "imagens primordiais" [...] como foram designadas acertadamente por Jakob Burckhardt, ou seja, "a aptidão hereditária da imaginação humana de ser como nos primórdios...". Um engano freqüente é acreditar que Jung considerava hereditárias as imaginações que nos acometem. Para ele, hereditário "é apenas a capacidade de ter tais imagens".

Em suas inúmeras viagens e em seus estudos de mitologia e literatura universal, Jung observou que certos temas são comuns a todas as culturas, em todas as épocas. [...] Haveria, assim, uma espécie de aptidão do ser humano de reproduzir as mesmas idéias míticas. "A essas imagens e correspondências típicas, denomino representações arquetípicas, pois têm suas origens nos arquétipos."

Os arquétipos são "possibilidades" que existem em todo ser humano. [...] Pode-se afirmar, por exemplo, que toda pessoa tem o arquétipo do herói latente, passível de ser "invocado" em determinados momentos, como nas catástrofes. Graças à necessidade, a pessoa apelará para uma coragem desconhecida e enfrentará a situação com determinação inabalável. Diríamos que a possibilidade de agir heroicamente reside em todo ser humano, pois é arquetípica. Já a atuação desse arquétipo dependerá de uma situação que o ative, e vai ter a forma que aquela personalidade consegue imprimir. Os arquétipos são "invisíveis" à consciência, mas expressam-se por imagens, idéias ou representações arquetípicas. Essas representações dos arquétipos encontram-se fartamente nos mitos, contos de fadas e sonhos. 
Pois bem, se estabelecermos uma analogia entre a atuação de um determinado indivíduo que age impregnado pelo arquétipo do herói, conforme exemplo dado por Bloise, e narrarmos a história de sua coragem numa situação determinada, temos aí uma narrativa de conquista e superação do medo. Essa conquista é pessoal, portanto a experiência é intransferível.

Vamos supor que esse indivíduo seja um executivo que saiu de férias com a família. A caminho da praia ou da montanha onde pretende descansar, acontece um acidente. Um ônibus tombado, repleto de passageiros, ameaça incendiar-se. Ignorando o risco pessoal, o executivo tenta salvar os feridos presos no veículo.

Tal ato de coragem poderia adquirir diversos caminhos narrativos, dependendo da visão do escritor que os relata. Não interessa, porém, qual seja o fim dessa aventura, se houve a morte dos passageiros ou o resgate; restará sempre o heroísmo arquetípico do indivíduo que se deu ao trabalho de, ao menos, tentar impedir uma tragédia.

Vejamos agora a história do heróico rei Arthur. Há inúmeras controvérsias sobre a "origem" do mito. Segundo alguns, ele faria parte do mundo celta; outros o consideram como o primeiro personagem lendário do universo cristão. De qualquer modo, trata-se da história de um rei. Se considerarmos a combinatória narrativa que impregna toda trajetória de conquista da coroa, teremos elementos como a descoberta da própria coragem, o chamado da aventura, o cumprimento de uma missão, a morte e a ressurreição. Digamos que essa estrutura seja arquetípica, no sentido de ser encontrada em diversas culturas. Já os detalhes e as especificidades da história arturiana, como a Távola Redonda, os cavaleiros e sua busca pelo cálice do Graal, a traição de Guinevere, a rainha, com Lancelot, o melhor amigo do rei, constituem elementos-chave dessa história em particular. Afirma o próprio Jung que o arquétipo assume uma grande riqueza de matizes, segundo cada manifestação. $A$ meu ver, em termos de narrativa, são esses matizes que fazem toda a diferença e 
constituem a autoria, mesmo que anônima, do narrador, no sentido que lhe atribui Walter Benjamin, de constituir-se como aquele que aconselha.

No exemplo do indivíduo que age impregnado pelo arquétipo do herói, temos um destino individual que se mescla a um destino ancestral. O mesmo se daria com as narrativas. O fato de serem geradas por arquétipos, as narrativas míticas, essas aventuras do espírito, como as designava Jung, não exclui sua movência. O medievalista Paul Zumthor (1993), em suas pesquisas no Nordeste brasileiro, por exemplo, encontrou preservadas diversas narrativas da Europa Medieval.

Não se trata, portanto, de uma exclusão binária, como propõe Warner: as histórias não são originais ou arquetípicas, sendo ambas as coisas simultaneamente. Cabe aqui retomarmos a metáfora do fermento, própria do pensamento sufi, conforme afirmava Idries Shah (1977, p. 76), "Faz-se o iogurte adicionando pequena quantidade de iogurte velho a uma quantidade maior de leite".

Bloise (2000, p. 158) afirma que Jung

descreve duas camadas no inconsciente: pessoal e coletivo. O inconsciente pessoal, resumidamente, assemelha-se ao inconsciente descrito por Freud. Contém tanto lembranças esquecidas como material que, não sendo aceito pela consciência, é reprimido.

Hoje, muitos autores não trabalham com essa separação tão nítida entre o inconsciente pessoal e o arquetípico. Entende-se que os arquétipos se manifestam e confundem-se com as experiências da pessoa. Por isso Jung chamava o inconsciente pessoal de subjetivo, no sentido de fazer parte do sujeito.

Já o inconsciente coletivo representa a parte objetiva da psique. É como outro "eu" dentro de nós, composto pelos instintos e arquétipos. Estes não nos pertencem com exclusividade, mas a toda humanidade, independendo da época ou cultura. São impessoais, ou suprapessoais. Os arquétipos são "simultaneamente, sentimento e pensamento" e teriam uma espécie de vida própria. [...] 
Por meio do conceito de inconsciente coletivo, Jung faz uma ponte entre a psique e o cosmos, ou seja, entre a psique e a matéria. Essa ligação é importante, pois aproxima-se da idéia taoísta de um continuum entre corpoespírito, e também por tentar explicar a ocorrência dos eventos sincrônicos.

Talvez possamos aproximar o conceito semiótico de textos constantes às narrativas arquetípicas e ressaltar a idéia da continuidade e da organicidade presentes tanto na definição de semiosfera, de Lotman, como na visão junguiana do inconsciente coletivo. Tanto um pensador quanto o outro, cada um partindo de visadas singulares, apontam para a complexidade das redes de criação inerentes à literatura, ampliando seu enfoque para além da cronologia, além do cânone, além do gênero, além do conceito romântico da criação como fruto da imaginação e criatividade de um artista isolado na solidão de sua genialidade única.

Afirma Lotman (1996, p. 293):

O caminho percorrido pelas investigações semióticas durante os últimos vinte anos permite tomar muitas coisas de outro modo. Como agora podemos supor, não existem por si mesmos, de modo isolado, sistemas precisos e funcionalmente unívocos que funcionam realmente. A separação destes está condicionada unicamente por uma necessidade heurística. Tomados separadamente, nenhum deles tem, na realidade, capacidade de funcionar. Só funcionam estando submersos num continuum semiótico, completamente ocupado por formações semióticas de diversos tipos e que se encontram em diversos níveis de organização. A esse continuum, por analogia com o conceito de biosfera introduzido por V. I. Vernardski, chamaremos de semiosfera. [...] Somente dentro de tal espaço resultam possibilidades de processos comunicativos e produção de nova informação. ${ }^{11}$

11 "El camino recorrido por las investigaciones semióticas durante los últimos veinte anos permite tomar muchas cosas de otro modo. Como ahora podemos suponer, no existen por si solos en forma aislada sistemas precisos y funcionalmente unívocos que funcionan realmente. La separación de éstos está condicionada únicamente por una necesidad heurística. Tomado por separado, ninguno de ellos tiene, en realidad, capacidad de trabajar. Solo funcionan estando sumergidos en un continuum semiótico, completamente ocupado por formaciones semióticas de diversos tipos y que se 
A escrita e sua fixidez, porém, talvez sejam parcialmente responsáveis pelos conceitos de autoria e originalidade. Em seu estudo sobre literatura oral, Paul Zumthor (1993) conta-nos que o uso da escritura permaneceu restrito até o ano 1000 a alguns mosteiros e cortes, expandindo-se com muita lentidão. Só no decorrer do século XIII é que se mostram, em Paris e Bolonha, os primeiros sinais de comércios de livros. Naquela época, a técnica da escritura era difícil de dominar e exigia rara competência. Inscrever um texto qualquer comportava duas opções: recolhê-lo sobre tabuinhas de cera e, em seguida, passá-lo a limpo sobre o pergaminho. Em geral, os textos eram ditados pelo autor ao seu secretário, que os anotava cuidadosamente.

Como a leitura e a escrita eram atividades restritas a uma minoria, havia a necessidade de intérpretes autorizados. Leitores profissionais que, pouco a pouco, passaram a ter mais prestígio que os contadores de histórias; daí o surgimento de segmentos afastando a cultura popular da erudita.

Além disso, para os antigos monges copistas da Idade Média, a escrita tinha um sentido religioso, sacro, que perduraria até a invenção da imprensa. Para eles, mais do que um meio de ação, a escrita era basicamente um dom divino.

A noção de texto autêntico contém um pensamento relativo à palavra de Deus. "A cultura ocidental, à medida que, desde o século XII, já se laicizava, transferia assim aos detentores da escrita a velha concepção teológica do locutor divino", afirma o pesquisador (Zumthor, 1993, p. 280), que nos alerta ainda:

Pensar "literatura" a propósito disso, com as conotações que lhe parasitam a idéia, é correr o risco de um fechamento elitizante. Também de um fechamento etnocêntrico, numa experiência historicamente limitada, própria das nações européias e americanas dos séculos precedentes. Desde

hallan en diversos niveles de organización. A ese continuum por analogía con el concepto de biosfera introducido por V. I. Vernadski, lo llamamos semiosfera." 
então se falseiam as perspectivas, tão logo o olhar se desloca no espaço ou no tempo. (Zumthor, 1993, p. 280)

À obra de Paul Zumthor e a maneira pela qual contesta a autoria canônica, Jerusa Pires Ferreira insere o conceito de semiose participante, segundo a concebe o russo luri Lotman, ou o exercício da observação viva. Uma percepção da voz, da poética da criação, que abrangeria desde as antigas línguas em extinção, até "as canções contemporâneas, dos roqueiros e metaleiros e seus aparatos". (Pires Ferreira, 2004, p. 83)

"A psique", afirma Bloise (2000, p. 14), "ou o próprio ser humano, nunca será contida dentro de um corpo de saber. É fundamental que procuremos explicações segundo várias perspectivas, como a ciência, a metafísica, a religião e a arte".

Não deixa de ser curioso observar que a teoria semiótica encontra na memória cultural a mesma qualidade vital e cambiável presente tanto no ancestral taoísmo chinês quanto no milenar pensamento sufi. É quase como se, após um longo período de ilusões classificatórias e tecnicistas, os pensadores relembrassem a percepção da ordem orgânica, o padrão que os taoístas chamavam de Li, um caminho assimétrico, não repetitivo e não organizado, "como o padrão da água em movimento". (Bloise, 2000, p. 33).

Ou ainda, dentro da arte poética sufi, compreender os tempos, as palavras e a vida é, simplesmente, tornar-se o mar: 


\section{A lua e o mar}

De The Diwan of Shams-i-Tabriz, por Mevlana Jelaluddin Rumi, Anatólia, século XIII

Ao amanhecer, a lua apareceu

e desceu de uma vez do céu para dar uma olhada em mim.

Como um falcão caçando uma presa,

a lua me segurou e lá fomos nós!

Eu procurei o meu eu, mas o meu eu se fora:

Na lua, pela graça, meu corpo virara como que alma.

Luminoso, eu viajei como alma, mas tudo o que vi foi aquela lua -

Até que o mistério do Eu e do eu ficou bem claro.

Nove tipos de céus, nove vibrações, todas misturadas

naquela lua;

e os limites do meu ser desapareceram no mar.

As ondas quebraram.

A consciência levantou-se de novo

e emitiu uma voz.

Sempre acontece assim.

O mar volta sobre si mesmo e espuma:

Com cada pedaço espumante

outro corpo, outro ser toma forma.

E quando o mar profere palavra,

cada corpo espumante 
torna a fundir-se imediatamente no sopro do oceano.

Graças ao meu amado amigo Sham'l Haqq, Sol da Verdade!

Sem a sua força

eu não poderia ver a lua,

eu não poderia tornar-me o mar.

Douglas-Klotz, Sabedoria do deserto. 
Posfácio 
Coisas opostas trabalham juntas, ainda que se oponham nominalmente.

Rumi 
Ao término da escritura desta tese, Philippe Willemart alertou-me para o fato de que Lacan, a principal referência de seu trabalho enquanto pesquisador, e Jung não concordavam acerca do conceito de arquétipo. Para Lacan, o renascimento do conceito de arquétipo só seria interessante a título mítico. 0 importante, para ele, seria alcançar articulações simbólicas que possibilitassem um modo de percepção capaz de caracterizar determinada realidade. A cura pela palavra se tornaria uma via a ser percorrida a partir do momento em que fosse respeitada a simbologia pessoal e intransferível do analisando.

Pois bem, na medida em que Willemart permitiu que eu me referisse à obra de Jung, sem eliminar comentários constantes à sua própria pesquisa, mesmo que esta tivesse sido baseada nos escritos de um pensador antagônico, agiu de acordo com a premissa primordial do próprio Lacan, grande defensor da liberdade e da autonomia de pensamento.

Quando levantei a hipótese daquilo que eu considerava ser a "história oculta" da literatura, ou seja, a influência da literatura sufi em diversos autores, Willemart afirmou que esses ecos faziam parte de minha escuta e que, portanto, mereciam ser tratados com respeito.

Ao meu mestre, a gratidão pela permissão de voar.

Ensinar pelo silêncio.

Trabalhar pelo Não-agir. Raros no mundo são aqueles que o praticam. 


\section{Bibliografia}

ABRAMS, M. H.; DONALDSON, E. Talbot; SMITH, Hallett; ADAMS, Robert M.; MONK, Samuel Holt; LIPKING, Lawrence; FORD, George H.; DAICHES, David. The Norton anthology of English Literature, v. 1 and 2. London: Norton, 1979.

ALMEIDA SALLES, Cecilia. Gesto inacabado: processo de criação artística. 2. ed. São Paulo: Annablume, 2004.

. Redes da criação: construção da obra de arte. Vinhedo: Horizonte, 2006.

ANDERSEN, Hans Christian. The Penguin Complete Fairy Tales and Stories of Hans Andersen. London: Penguin Books, 1974.

BAKHTIN, Mikhail. Questões de literatura e estética: a teoria do romance. São Paulo: Unesp, 1988.

BARCIA GOMES, Purificación. O método terapêutico de Scheerazade: mil e uma histórias de loucura, desejo e cura. São Paulo: Iluminuras, 2000.

BAUMAN, Zygmunt. Culture as praxis. Paris: Sage Publications, 2000. . Liquid modernity. Cambridge: Polity Press, 2003.

BENJAMIN, Walter. Obras escolhidas. São Paulo: Brasiliense, 1987.

BERGER, Henri. Legendes et contes du Maroc. Paris: Grund, 1992.

BEUISSET, Ariane. Le Dernier tableau de Wang Wei. Paris: Albin Michel, 1988.

BLOISE, Paulo V. O tao e a psicologia. São Paulo: Angra, 2000.

BORGES, Jorge Luis. Siete noches. México, D.F.: Fondo de Cultura Económica, 1999. Col. Tierra Firme.

. Obras completas III. São Paulo: Globo, 2004. 
BOURGE, Jean-Loup. L'Histoire au cinema: le passé retrouvé. Paris: Gallimard, 1992.

BRADLEY, Beatty; LONG, Perkins. The American tradition in literature. New York: Norton, 1976.

BRETON, André. Manifestes du surréalisme. Paris: Gallimard, 1979. Folio.

CAMPBELL, Joseph. Oriental Mythology. New York: Penguin, 1962. . O poder do mito. São Paulo: Palas Athenas, 1988.

CAMPOS, Haroldo. A arte no horizonte do provável. São Paulo: Perspectiva, 1972.

CARTMELL, Deborah; WHELEHAN, Imelda. Adaptations from text to screen, screen to text. London: Routledge, 1999.

CHION, Michel. Ecrire un Scenario. Cahiers du Cinema. Paris, 1985.

CHITTICK, C. William. Sufism: a short introduction. Oxford (USA): Oneworld Publications, 2000.

COTIDIANUS. Memorial Jorge Luis Borges. Disponível em: <http://www.gun.com.br/borges/port.htm>. Acesso em: 15 ago. 2005.

COTTERELL, Arthur. The encyclopedia of Mythology. London: Lorenz Books, 1996.

DE LA BARCA, Pedro Calderón. La Vie est um songe. Paris: Gallimard, 1996.

DOUGLAS-KLOTZ, Neil. Sabedoria do deserto. Rio de Janeiro: Nova Era, 1996.

DUMAS, Alexandre; FÉVAL, Paul; SCOTT, Walter; CERVANTES, Miguel de; STEVENSON, Robert Louis; WALLPOLE, Horace; VON GRIMMELSHAUSEN, Hans. Conte de la Chevalerie. Paris: Grund, 1992.

DURRELL, Lawrence. Le Sourire du Tao. Paris: Gallimard, 1980. Folio.

ELIADE, Mircea. Initiation, rites, sociétés secretes. Paris: Gallimard, 1959. Folio.

GAGNEBIN, Jeanne-Marie. Posfácio. In: PROUST, Marcel. Em busca do tempo perdido. Volume 1: No caminho de Swann. Trad. Mário Quintana. São Paulo: Globo, 2006. 
GIRAUD, Daniel. Livre de Tao: Li Po, voyageur, poète et philosophe. Paris: Albin Michel, 1989.

GOUGAUD, Henri. L’Arbre aux trésors. Paris: Éditions du Seuil, 1987.

GRAVES, Robert. Les Mythes Grecs. Tomes 1 et 2. Paris: Fayard, 1967. . Introdução. In: SHAH, Idries. Os sufis. São Paulo: Cultrix, 1977.

GRIMAL, Pierre. Dictionnaire de la mythologie grecque et romaine. Paris: Presses Universitaires de France, 1988.

HELLER, Julek; HEADON, Deirdie. King Arthur and his knights. Great Britain: Dragon's World, 1990.

HULPACH, Wladimir. Légendes Celtes. Paris: Grund, 2000.

IGNÁCIO DA SILVA, Guilherme. Prefácio. In: PROUST, Marcel. Em busca do tempo perdido. Volume 1: No caminho de Swann. Trad. Mário Quintana. São Paulo: Globo, 2006.

IRWIN, Robert. Night and horses and the desert. The Penguin Anthology of Classical Arabic Literature. London: Penguin, 1999.

JACOBS, Joseph. More Celtic fairy tales. New York: Dover Publications, 1968.

JOLLES, Andre. Formas simples. São Paulo: Cultrix, 1989.

JULLIEN, François. Entretien. L'Oulipo Magazine Littéraire, n. 3980. Paris, mai.2001.

JUNG, Carl Gustav. Entrevistas e encontros. São Paulo: Cultrix, 1977. Sincronicidade. Petrópolis (RJ): Vozes, 1984. . Aion: estudos sobre o simbolismo do si-mesmo. Petrópolis (RJ): Vozes, 1988. . Essais sur la Symbolique de l'esprit. Paris: Albin Michel, 1991. . Os arquétipos e o inconsciente coletivo. 4. ed. Petrópolis (RJ): Vozes, 2006. KIELCE, Anton. O taoísmo. São Paulo: Martins Fontes, 1984.

LAMBERT, Marie Théresè. Le Tao. Paris: Robert Laffont, 1981. Collection Miroir du Monde. 
LANG, Andrew. Tales of Troy and Greece. Wordsworth: Classics, 1995.

LAO-TSÉ. Tao Te King. Trad. Marcos Martinho dos Santos. São Paulo: Attar Editorial, 1995.

LEGENDES de dragons: récits chinois. Beijing: Editions Littérature Chinoise, 1988. Collection Panda.

LESSING, Doris. Les Carnets de Jane Sommers: si la vieillesse pouvait. Paris: Albin Michel, 1985.

. Idries Shah Died London, November 23, 1996. Extraído do obituário do jornal London Daily Telegraph. Disponível em <http://mural.uv.es/vemivein/on.htm>. Acesso em: 15 ago. 2005.

LÉVI-STRAUSS, C. Myth and meaning. London: Routledge, 2001.

LEYRIS, Pierre. La Bataille des oiseaux: contes celtiques choisis et adaptes. Paris: Hatier, 1998.

LIEH-TZU. A Taoist guide to practical living. Trad. Eva Wong. Boston/London: Shambhala Dragon Editions, 1995

LOTMAN, Iuri M. La semiosfera: semiótica de la cultura y del texto. Madrid: Frónesi Cátedra, Universidad de Valencia, 1996.

MANGUEL, Alberto; GUADALUPI, Gianni. The dictionary of imaginary places. London: Bloosmbury, 1999.

MARDRUS, Joseph Charles (trad.). Les Mille et une nuits. Tomes 1 et 2. Paris: Robert Laffont, 1980.

MAUROIS, André. Les Trois Dumas. Paris: Robert Laffont, 1993.

MIRANDA, Álvaro. Uma conversa com Jorge Luis Borges. Disponível em: <http://www.secrel.com.br/jpoesia/1amiranda.html>. Acesso em: 15 ago. 2005.

ONG, Walter. Oralidade e cultura escrita. São Paulo: Papirus, 1998.

OULIPO. La Literature pontentielle. Paris: 1988. Folio; essays. 
PEREIRA GONÇALVES, Maria Teresa; ANTUNES, Benedito (orgs.). Trança de histórias. São Paulo: Unesp, 2004.

PESSOA, Fernando. Quando fui outro. Rio de Janeiro: Alfaguara/Objetiva, 2006.

PIRES FERREIRA, Jerusa. Armadilhas da memória. São Paulo: Ateliê Editorial, 2004.

PRIETO, Heloisa. Rei Arthur, Dom Quixote e D'Artagnan: sendas e sonhos de lendários heróis. Dissertação de mestrado. Pontifícia Universidade Católica de São Paulo, 1996.

. Lá vem história. 7. ed. São Paulo: Companhia das Letras, 2003.

. Lá vem história outra vez. 6. ed. São Paulo: Companhia das Letras, 2004.

. O jogo da parlenda. São Paulo: Companhia das Letras, 2005.

. A panela da paz. São Paulo: Ática, 2006.

PRIETO, Heloisa; BLOISE, Paulo. O imperador amarelo. São Paulo: Moderna, 2006.

PROUST, Marcel. Les Plaisirs et les jours. Paris, 1924.

. Lê Cote de Guermantes. Paris: Gallimard, 1954. Folio.

. Un Amour de Swan. Paris: Gallimard, 1954. Folio.

. Du Cote de chez Swan. Paris: Flammarion, 1987.

. Le Temps retrouvé. Paris: Gallimard, 1989. Folio.

. Em busca do tempo perdido. Volume 1: No caminho de Swann. Trad. Mário Quintana. São Paulo: Globo, 2006.

REIS, Vladimir. Contes des cinq continents. Paris: Grund, 1986.

REY, Pierre-Louis; ROGERS, Brian G. Prefáce. In: PROUST, Marcel. Le Temps retrouvé. Paris: Gallimard, 1990.

RISPAIL, Jean-Luc. Les Surréalistes: une géneration entre le revê e l'action. Paris: Gallimard, 1991.

ROBERTS, Moss. Chinese fairy tales \& fantasies. New York: Pantheon Books, 1979. 
ROCHEDIEU, Edmond. Jung et l'Individu dans le monde d'aujourd'hui. Paris: Éditions Seghers, 1970. Coll. Philosophes de notre temps.

RÓNAI, Paulo; FERREIRA, Aurélio Buarque de Holanda. Mar de histórias. Rio de Janeiro: Nova Fronteira, 1978.

SHAH, Idries. Histórias dos dervixes: histórias instrutivas dos mestres sufis nos últimos mil anos. Rio de Janeiro: Nova Fronteira, 1976. . Os sufis. São Paulo: Cultrix, 1977.

SHIRES, Cohan \& Linda M. Telling stories: a theoretical analysis of narrative fiction. London: Routledge, 1988.

SQUIRE, Charles. Celtic myths and legends. New York: Gramercy Books, 1994.

STWICKOVA, Dana \& Milada. Contes Chinois. Paris: Grund, 1969.

TICHY, Jaroslav. Legendes et contes Persans. Paris: Grund, 1989.

VACLAV, Cibula. Contes des fous sages. Paris: Grund, 1985.

WERNER, Edward T. C. Myths and legends of China. Singapore: Graham Brash, 1991.

WARNER, Marina. Da fera à loira: sobre contos de fadas e seus narradores. São Paulo: Companhia das Letras, 1999.

WILDE, Webster Lyn. Le Monde des celtes: traditions. Paris: Clin D'Oeil/Grund, 2005.

WILLEMART, Philippe. Proust, poeta e psicanalista. São Paulo: Ateliê Editorial, 2000.

. Crítica genética e psicanálise. São Paulo: Perspectiva, 2005.

WONG, Eva. Tales of the Taoist immortals. London: Shambala, 2001.

YEATS, W. B. Fairy and folk tales of Ireland. New York: Macmillan/Collier Books, 1986.

YOURCENAR, Marguerite. Nouvelles orientales: l'imaginaire. Paris: Gallimard, 1963. 
ZUMTHOR, Paul. A letra e a voz. São Paulo: Companhia das Letras, 1993. Introdução à poesia oral. São Paulo: Educ, 1997. 